\title{
INTEGRASI NILAI MULTIKULTURAL DALAM PEMBELAJARAN PENDIDIKAN AGAMA ISLAM DI DAERAH PASCA KONFLIK
}

\author{
Saepudin Mashuri \\ IAIN Palu \\ Email: din.mashuri@gmail.com
}

\begin{abstract}
Abstrak
Artikel ini berkenaan dengan integrasi nilai multikultural dalam pembelajaran PAI di sekolah dengan setting sosial masyarakat Poso pasca konflik yang sedang membangun perdamaian. Penelitian ini bertujuan untuk mengungkapkan proses integrasi nilai multikultural dalam pembelajaran PAI di SMKN 1 dan SMAN 3 Poso, Sulawesi Tengah. Penelitian ini menggunakan pendekatan kualitatif dengan studi multisitus di dua sekolah yang memiliki karakteristik umum yang sama. Teknik pengumpulan data, yaitu: wawancara mendalam, observasi partisipan dan studi dokumentasi. Analisis data dilakukan dengan metode komparatif konstan untuk menemukan persamaan, perbedaan dan hubungan temuan penelitian di kedua situs. Hasil penelitian ini menunjukkan bahwa nilai multikultural yang diintegrasikan di kedua sekolah adalah kontekstual dengan realitas keragaman peserta didik, masyarakat dan upaya membangun perdamaian di sekolah dan daerah Poso pasca konflik. Kemudian, nilai multikultural yang diitegrasikan bersifat universal yang mencakup: saling memaafkan, kasih sayang, saling menghormati, kepedulian, toleransi, kebersamaan dan perdamaian. Proses integrasi nilai multikultural dilakukan melalui empat pendekatan, yaitu: formal-tekstual, sosial-kontekstual, kontributif-kultural dan aditif-tematik dengan empat bentuk integrasi, meliputi: normatif, interpersonal, sosial dan budaya lokal.
\end{abstract}

Kata Kunci: Integrasi, Nilai Multikultural, Pembelajaran PAI, Perdamaian, Sekolah Pasca Konflik

\section{Abstract}

This paper deals with multicultural values integration in Islamic education learning takes place on the social setting of post-conflict schools and society who are building peace. The purpose of this study is to reveal the process of multicultural values integration in Islamic education learning at di SMKN 1 dan SMAN 3 Poso, Central Sulawesi. The study is a qualitative approach with multi-sites study in two schools with same general characteristics. The data collection techniques are: in-depth interview, partisipant observation, and document study. Analysis was carried out by comparative constant analysis to find smillarities, difference, and correlation of the results of the 
research in two schools. The results of the study indicate that integration of multicultural values in Islamic education learning in both schools are contextual with the reality of students diversity, society and effort to build peace in the post-conflict schools and Poso area. Then, the integrated of multicultural values is universal. The values are forgiveness, compassion, mutual respect, care, tolerance, togetherness, and peace. The process of multicultural values integration in Islamic education learning in both schools has been performed through four approaches. The approaches consist of: formal-textual, social-contextual, contributive-cultural, and additive-thematic. While its forms of the integration include: normative, interpersonal, social, and local culture.

Key Words: Integration, Multicultural Values, Islamic Educatin Leaning, Peace, Post-Conflict Schools

\section{PENDAHULUAN}

Integrasi antara komunitas yang berbeda menjadi salah satu dimensi mendasar dalam kajian Sosiologi. Menurut penganut teori fungsional struktural, meskipun masyarakat pluralistik mudah mengalami perpecahan dan konflik, tetapi struktur kehidupan sosial termasuk agama selalu menjalankan fungsinya menciptakan kondisi masyarakat yang stabil dan teratur (kohesif). ${ }^{1}$

Secara mendasar, integrasi bertujuan membangun kebersamaan antara komunitas masyarakat yang berbeda berdasarkan konsesus bersama yang telah disepakti. Pada posisi ini, integrasi interpersonal, sosial dan budaya memiliki peran penting membangun integrasi masyarakat dan bangsa.

Integrasi dapat mempersatukan komunitas yang berbeda membentuk kekuatan bersama dalam membangun kehidupan masyarakat dan bangsa yang damai. Menurut Mahfud, masyarakat yang terdiri dari berbagai daerah, suku, agama dan budaya terintegrasi menjadi kesatuan nasional untuk membentuk kekuatan yang lebih besar berdasarkan satu spirit kebangsaan. ${ }^{2}$

Dalam konteks kemajemukan bangsa Indonesia, integrasi sosial dan budaya menuju terbentuknya konsesus bersama dapat terwujud dalam kehidupan masyarakat jika komunitas yang berbeda memiliki pemahaman dan sikap inklusif dalam beragama. Selain itu, integrasi sosial membutuhkan keterpaduan yang saling mendukung antara unsur-unsur kehidupan di suatu

${ }^{1}$ Adon Nasrullah Jamaludin, Agama \& Konflik Sosial: Studi Kerukunan Umat Beragama, Radikalisme, dan Konflik AntarUmat Beragama, (Bandung: Pustaka Setia, 2015), hlm. 60.

${ }^{2}$ Mahfud M.D, Demokrasi dan Konstitusi di Indoenesia, (Yogyakarta, Liberty, 1993), hlm. 71. 
bangsa, seperti: nilai, falsafah, aturan, agama, budaya, komunitas dan lembaga.

Pada posisi ini, integrasi nilai multikultural dalam pembelajaran PAI di sekolah pasca konflik Poso memiliki peran penting dalam menyemaikan nilai multikultural yang sejalan dengan normativitas agama Islam dan identitas nasional sehingga membentuk karakter bergama peserta didik yang toleran, peduli dan damai dengan komunitas agama lain. Dalam hal ini, integrasi nilai multikultural memiliki relevansi dengan konsep 'ashabiyah Ibnu Khaldun yang menekankan agar komunitas yang berbeda melakukan integrasi sosial dan budaya dalam kehidupan untuk membangun kekuatan bersama. $^{3}$

Integrasi nilai multikultural dalam pembelajaran PAI dalam konteks bangsa Indonesia, selain berdasarkan pada normativitas agama Islam, juga berpijak pada falsafah Pancasila dan kearifan budaya luhur masyarakat. Dalam konteks hubungan lintas agama dan budaya, nilai multikultural sebagai prinsip, baik secara personal maupun kolektif dalam membangun kehidupan damai sesuai konteks kemajemukan bangsa Indonesia agar masyarakat tidak mudah terseret pada perpecahan, konflik dan disintegrasi.

Secara prinsipil, integrasi nilai multikultural dalam pembelajaran PAI sebagai upaya untuk menghadirkan pembelajaran yang inklusif. Sehingga antara peserta didik muslim dan umat agama lain mampu saling berintegrasi dalam membangun perdamaian di sekolah dan masyarakat Poso pasca konflik.

Integrasi nilai multikultural dalam pembelajaran PAI di sekolah pasca konflik berlangsung, baik secara formal-tekstual di kelas maupun secara informal-kontekstual melalui kegiatan keagamaan, ekstra kurikuler, aksi sosial dan kemanusiaan. Perpaduan kedua teknik integrasi nilai multikultural tersebut membentuk karakter beragama peserta didik yang mendukung terbangunnya perdamaian di sekolah dan masyarakat Poso pasca konflik.

\section{Konsep Integrasi Nilai Multikultural}

\section{Pendekatan Integrasi Materi Multikultural}

Secara etimologi, integrasi dalam Kamus Besar Bahasa Indonesia Online bermakna pembauran sampai menjadi kesatuan yang utuh dan bulat. ${ }^{4}$ Secara terminologi, Moodod dalam karya Race berjudul, Multiculturalism and Education, mendefinisikan integrasi

3 Ibnu Khaldun, Muqaddimah Ibn Khaldun, Terj. Ahmadie Thoha, (Jakarta: Pustaka Firdaus, 2000), hlm. 371.

4 Kamus Besar Bahasa Indonesia Online, https://www.kbbi.my.id/kata/integrasi. Diakses, tanggal 15 November 2019. 
sebagai interaksi sosial dua arah, antara kelompok etnis mayoritas dan minoritas dalam proses berintegrasi. ${ }^{5}$ Sedangkan Mitchell dan Salsbury memaknai integrasi adalah sebuah terma multikultural yang barkaitan dengan penghapusan perbedaan (segregasi) antara manusia. ${ }^{6}$

Dalam konteks integrasi materi multikultural dalam pembelajaran suatu bidang studi di sekolah, Banks melalui teori the content integration approach mengemukakan empat pendekatan integrasi dengan mem-pertimbangkan realitas keragaman peserta didik, setting sosial masyarakat dan daerah.

Menurut Banks, integrasi materi multikultural dalam pembelajaran dapat dilakukan pada semua disiplin ilmu, baik eksak maupun sosial termasuk pendidikan agama. Secara prinsipil, integrasi materi multikultural ke dalam bidang studi adalah upaya guru menggunakan nilai, tema, prinsip, dan contoh multikultural dalam pembelajaran. $^{7}$

Banks membagi pendekatan integrasi materi multikultural ke dalam suatu bidang studi menjadi empat tingkat, yaitu: melalui pendekatan kontribusi (contribution approach), pendekatan aditif (additive approach), pendekatan transformasi (transformation approach) dan pendekatan aksi sosial (social action approach). ${ }^{8}$

Pertama, pendekatan kontribusi sebagai tahap pertama yang diperuntukkan bagi pendidik yang baru mulai mengintegrasikan materi multikultural dalam pembelajaran. Pendekatan kontribusi dimaknai sebagai proses mamasukkan unsur kebudayaan sebagai muatan materi multikultural suatu mata pelajaran.

Menurut Banks, materi multikultural pada pendekatan kontribusi meliputi: tema budaya dan praktik keagamaan. Misalnya, gambar pahlawan, simbol kesukuan, bahasa, kesenian, tradisi, benda sejarah, hari libur nasional, festival budaya dan hari besar keagamaan. Semua materi multikultural tersebut dapat diintegrasikan dalam pembelajaran sesuai karakteristik, tujuan bidang studi dan kondisi daerah suatu bangsa.

Pada pendekatan kontribusi, selain tidak dilengkapi dengan buku paket khusus juga tidak merubah struktur dasar, tujuan dan

5 Ricard Race, Multiculturalism and Education: Comtemporary Issues in Education Studies, (Great Britain, Continuum, 2011), hlm. 19.

${ }^{6}$ Bruce M. Mitchell and Robert E. Salsbury, Encyclopedia of Multicultural Education, (London: Greenwood Press, 1999), hlm. 109.

${ }^{7}$ James A. Banks and Cherry A. McGee Banks, Multicultural Education: Issues and Perspective, (Ed.VII, USA: Wiley \& Sons, Inc. 2010), hlm. 237.

${ }^{8}$ Banks and Banks, Multicultural ..., hlm. 238. 
karakter kurikulum yang berlaku. Pendekatan ini bertujuan memahamkan peserta didik tentang keragaman masyarakat dan bangsa agar tumbuh sikap hormat pada keragaman yang mereka miliki.

Kedua, pendekatan aditif dilaksanakan dengan menambahkan tema, konsep dan perspektif keragaman budaya menjadi muatan kurikulum mata pelajaran tanpa merubah struktur, tujuan dan karakter dasar kurikulum yang berlaku. Pendekatan aditif menjadi fase awal transfomasi kurikulum multikultural secara sempurna. ${ }^{9}$

Pendekatan aditif memiliki cakupan yang lebih luas dari kontribusi. Selain menambah materi keragaman budaya, juga dilengkapi dengan modul, panduan dan unit kajian khusus dengan melibatkan aktor seperti: sejarawan, penulis, artis, budayawan dan ilmuwan. Pendekatan ini bertujuan untuk memahamkan peserta didik perspektif para tokoh terkait hubungan lintas budaya, baik ketika menjadi mayoritas maupun minoritas.

Ketiga, pendekatan transformasi dalam pembelajaran multikultural berbeda secara fundamental dengan pendekatan kontribusi dan aditif. Pendekatan transformasi mengharuskan perubahan kurikulum yang berlaku secara total menjadi kurikulum multikultural sepenuhnya. Pendekatan ini dilengkapi buku dengan muatan kurikulum dari seluruh aspek perbedaan kebudayaan masyarakat suatu negara. Tujuan pendekatan ini memahamkan peserta didik tentang konsep, nilai, tema, isu, peristiwa multikultural dari perspektif komunitas budaya berbeda. ${ }^{10}$

Keempat, pendekatan aksi sosial merupakan level pembelajaran multikultural tertinggi mencakup semua elemen yang ada pada pendekatan transformasi. Pada pendekatan ini, peserta didik diajarkan pengetahuan dan keterampilan menyikapi ketimpangan sosial yang terjadi di masyarakat. Tujuan pendekatan ini untuk memfasilitasi peserta didik melakukan kritik sosial ke arah perubahan kehidupan masyarakat yang berkeadilan. ${ }^{11}$

Sedangkan Rahman dkk menyebutkan tiga model integrasi nilai multikultural dalam pembelajaran PAI di sekolah, yaitu: integrasi langsung dan tidak langsung, tematik, laboratorium sosial. ${ }^{12}$ Pada integrasi langsung dan tidak langsung, guru mengacu pada materi PAI

${ }^{9}$ Banks and Banks, Multicultural ..., hlm. 240-241.

${ }^{10}$ Banks and Banks, Multicultural ..., hlm. 243-244.

${ }^{11}$ Banks and Banks, Multicultural ..., hlm. 245-246.

12 H. Abd. Rahman dkk, Panduan Integrasi Nilai Multikultural dalam Pendidikan Agama Islam pada SMA dan SMK, (Jakarta: PT. Kirana Cakra Buana, 2011), hlm. 120-121. 
yang termuat dalam silabus. Pada integrasi tematik, guru mengintegrasikan tema multikultural sebagai muatan pembelajaran PAI. Pada integrasi laboratorium sosial, guru memfungsikan sentra sosial di sekolah seperti: mushalla, unit-unit ekstra kurikuler dan kegiatan sosial.

\section{Nilai Multikultural}

Secara etimologi, nilai berasal dari bahasa Latin, yaitu vale're yang bermakna: berguna, bermanfaat dan berdaya. Sedangkan pengertian nilai secara terminologi dijelaskan Adisusilo, yaitu sesuatu yang dipandang baik, benar dan bermanfaat menurut keyakinan seseorang atau sekelompok. ${ }^{13}$

Walaupun nilai bersifat abstrak, tetapi memiliki indikator yang dapat diamati dalam interaksi kehidupan sosial manusia. Menurut Raths dalam Adisusilo, nilai memiliki beberapa indikator, yaitu: memberikan arah tujuan yang akan dicapai, memberikan inspirasi dalam bertindak, mengarahkan seseorang dalam bertingkah laku, menarik perasaan, berkaitan dengan keyakinan dan agama serta nilai muncul dari kesadaran diri, hati nurani, pikiran ketika seseorang menghadapi persoalan hidup. ${ }^{14}$

Dari segi sifatnya, Amin Abdullah membagi nilai menjadi dua jenis, yaitu: pertikular dan universal. ${ }^{15}$ Nilai pertikular bersifat eksklusif, karakteristik khas setiap agama atau komunitas budaya dan menjadi pembeda dengan yang lain. Sedangkan nilai universal bersifat inklusif, dimiliki semua komunitas agama atau budaya dan dapat diterima oleh komunitas yang berbeda untuk menyatukan segala perbedaan.

Azyumardi Azra mengemukakan ranah dan jenis nilai multikultural yang perlu diintegrasikan dalam pembelajaran di sekolah untuk merawat kemajemukan bangsa Indonesia meliputi: toleransi, tema perbedaan etno kultural, agama, bahaya diskriminasi, resolusi konflik, HAM, demokrasi, pluralitas dan kemanusiaan universal. ${ }^{16}$

13 Sutarjo Adisusilo, Pembelajaran Nilai Karakter: Konstruktivisme dan VCT Sebagai Inovasi Pendekatan Pembelajaran Afektif, (Jakarta: PT. Raja Grafindo Persada, 2012), hlm. 56.

${ }^{14}$ Adisusilo, Pembelajaran..., hlm. 57-59.

15 M. Amin Abdullah, dalam Kata Pengantar: "Kesadaran Multikultural: Sebuah Gerakan "Interest Minimalization" dalam Meredakan Konflik Sosial" dalam M. Ainul Yaqin, Pendidikan Multikultural: Cross-Cultural Understanding untuk Demokrasi dan Keadilan, (Yogyakarta: Pilar Media, 2005), hlm. xiv.

16 Azyumardi Azra, Merawat Kemajemukan, Merawat Indonesia, (Yogyakarta: Kanisius, 2007), hlm. 27. 
Tholhah Hasan mengatakan bahwa nilai multikultural yang bersumber dari agama Islam memiliki karakteristik inklusif. Nilainilai inklusif yang penting ditransfer melalui proses pembelajaran di sekolah untuk mendorong terwujud budaya multikultural dalam kehidupan masyarakat Indonesia yang majemuk, yaitu: ta'aruf (saling mengenal), tawasshut (moderat), tasammuh (toleransi), ta'awun (saling menolong), keadilan ('adl) dan tawazun (harmoni). ${ }^{17}$

Sementara Ahmad Baidhawy menyebutkan nilai multikultural yang penting diintegrasikan dalam pendidikan agama seperti PAI, mencakup: belajar hidup dalam perbedaan, menghindari buruk sangka, saling percaya, memahami, menghormati, inklusif, apresiasi dan rekonsiliasi damai. ${ }^{18}$

Muatan nilai multikultural pada pelajaran PAI dan Budi Pekerti menurut Kurikulum 2013 tingkat SMA/SMK dikembangkan berdasarkan prinsip Islam rahmatan lil 'alamin yang humanis, toleran, demokratis dan damai. Pemuatan nilai-nilai inklusif-universal ini bertujuan agar peserta didik mampu menjadi pioner terciptanya harmoni kehidupan di tengah kemajemukan sekolah, masyarakat dan bangsa Indonesia. ${ }^{19}$

Dalam kajian ini, nilai multikultural yang diintegrasikan dalam pembelajaran PAI di sekolah pasca konflik bersifat kontekstual dengan realitas keragaman peserta didik, setting sosial warga sekolah dan masyarakat Poso dan upaya membangun perdamaian di sekolah pasca konflik. Nilai multikultural yang diintegrasikan dapat mempertemukan semua umat beragama dalam membangun perdamaian yang meliputi: saling memaafkan, kasih sayang, saling menghormati, kepedulian, toleransi, kebersamaan dan perdamaian.

\section{METODE PENELITIAN}

Penelitian ini menggunakan metode kualitatif jenis studi multisitus di dua lokus yang memiliki karakteristik umum yang sama. Data penelitian ini bersifat induktif, yaitu fenomena sosial di dua sekolah pasca konflik, meliputi: kebijakan pimpinan sekolah, proses integrasi nilai multikultural

17 Muhammad Tholhah Hasan, Pendidikan Multikultural sebagai Opsi Penanggulangan Radikalisme, (Malang: Universitas Islam Malang, 2016), hlm. 6072.

18 Zakiyuddin Baidhawy, Pendidikan Agama Berwawasan Multikultural, (Jakarta: Erlangga, 2005), hlm. 78-84.

19 Kementerian Pendidikan dan Kebudayaan, Silabus Mata Pelajaran Pendidikan Agama Islam dan Budi Pekerti SMA/MA/SMK/MAK, Edisi Revisi, (Jakarta: Kementerian Pendidikan dan Kebudayaan, 2016), hlm. 2. 
dalam pembelajaran di kelas, kegiatan sosial keagamaan dan kemanusiaan peserta didik lintas agama di sekolah atau masyarakat.

Secara prosedural, peneliti menjadi instrumen kunci sementara informan ditentukan secara sampling pada orang-orang tertentu yang kompeten memberikan informasi yang valid. Dalam pengumpulan data, peneliti menggunakan tiga tehnik, yaitu: wawancara mendalam (in depth interview), observasi partisipan (partisipant observation) dan studi dokumentasi (document study). ${ }^{20}$

Pada analisis data, Peneliti menggunakan analisis data interaktif dari Miles, Huberman dan Saldana yang terdiri dari: kondensasi data (data condensation), penyajian data (data display) dan penarikan kesimpulan (verification). ${ }^{21}$ Sedangkan pada analisis data lintas situs, peneliti menggunakan teori metode komparatif konstan (the constant comparative methode) dari Bogdan dan Biklen untuk membandingkan temuan dari kedua situs sehingga mendapatkan persamaan dan perbedaan sejumlah proposisi lintas situs. ${ }^{22}$

\section{Integrasi Nilai Multikultural dalam Pembelajaran PAI di Sekolah Pasca Konflik}

\section{SMKN 1 Poso}

Proses integrasi nilai mutikultural dalam pembelajaran PAI SMKN 1 Poso, baik secara tekstual di kelas maupun secara konstekstual di lingkungan sekolah atau masyarakat meliputi pendekatan dan bentuk integrasi diuraikan sebagai berikut:

\section{a. Pendekatan Integrasi Nilai Multikultural}

\section{1). Formal-Tekstual}

Pendekatan formal-tekstual merupakan proses pengintegrasian nilai multikultural dalam pembelajaran PAI berdasarkan materi yang termuat dalam silabus Kurikulum 2013. Pendekatan ini sangat berkaitan dengan karakteristik materi, apakah bercorak multikultural atau tidak. Selain itu, pendekatan ini terikat dengan KD, IPK hasil belajar yang akan dicapai peserta didik dan implementasi RPP yang telah didesain guru dalam pembelajaran di kelas.

20 Robert Bogdan dan Sari Knopp Biklen, Qualitative Research for Education; An Introduction to Theory and Methods, (London: Allyn and Bacon Inc, 1998), h. 119-143.

21 Matthew B. Milles, A. Michael Huberman and Johnny Saldana, Qualitative Data Analysis: A Methods Saourcebook, (Ed. III; USA: SAGE Publication.Inc, 2014), h. 10.

${ }^{22}$ Bogdan dan Biklen, Qualitative..., hlm. 70-76. 
Melalui pendekatan formal-tekstual, guru melakukan dua teknik integrasi, yaitu langsung dan tidak langsung. Pada materi yang bercorak multikultural, guru langsung mengintegrasikan nilai multikultural dengan KD dan IPK hasil belajar yang akan dicapai peserta didik. Terkait fakta tersebut, informan berikut menjelaskan:

Dalam kurikulum PAI 2013 ada nilai dan topik kontrol diri, toleransi, saling menghormati, menolong, bersikap adil dan menjaga persatuan. Pada materi tersebut, saya tinggal buatkan KD dan indikatornya. Nilai-nilai ini selalu saya tanamkan pada pembelajaran di kelas kemudian saya kaitkan dengan kehidupan sosial warga sekolah dan masyarakat Poso dalam membangun perdamaian. ${ }^{23}$

Sedangkan secara tidak langsung, guru mengintegrasikan nilai multikultural melalui materi pelajaran tentang teologi, ritual ibadah dan mua'malat menurut Islam yang termuat dalam silabus. Guru menarik pesan moral-substatif yang relavan diaktualkan oleh peserta didik dalam konteks membangun perdamaian umat beragama.

Pada materi asma'ul husna terdapat nilai perdamaian (ya salam), pada sholat jenazah ada nilai persatuan dan peduli, pada zakat ada nilai saling menolong, pada perkawinan ada nilai penghormatan pada keragaman, pada haji ada nilai kesetaraan dan keragaman, pada warisan ada nilai keadilan antara sesama manusia.

Melalui integrasi secara tidak langsung, peserta didik dapat memahami dan mengaktualisasikan ajaran moral-substantif dari aspek teologis, ritual ibadah dan mu' amalat dalam kehidupan sosial lintas agama di sekolah. Informan berikut menjelaskan: "Saya mengambil nilai intinya yang dapat diterapkan dalam kehidupan sosial antara siswa yang berbeda agama dan suku." ${ }^{24}$

\section{2). Sosial-Kontekstual}

Pendekatan sosial-kontekstual merupakan proses integrasi nilai multikultural dalam pembelajaran PAI dengan mengaitkan materi sesuai realitas keragaman peserta didik, berada di komunitas Kristen mayoritas, daerah Poso yang pernah konflik dan masyarakat yang membangun perdamaian umat beragama.

Melalui pendekatan sosial-kontekstual, guru mengintegrasikan nilai multikultural melalui berbagai kegiatan 
yang menjadi sentra sosial peserta didik muslim yang berbeda secara kultural. Integrasi nilai multikultural dengan pendekatan ini lebih banyak dilakukan melalui kegiatan keagamaan di islamic center, seperti: praktik ibadah setiap hari, Sabtu religi, PHBI dan pesantren kilat. Terkait proses integrasi nilai multikultural secara informal-kontekstual pada kegiatan keagamaan dijelaskan informan berikut:

Selain dalam pembelajaran PAI di kelas, siswa muslim dibina dalam kegiatan Sabtu religi. Sabtu religi sebagai rangkaian PAI di sekolah sebagai media membina ritual ibadah siswa secara vertikal dan sosial. Karakter personal dan sikap sosial pada warga sekolah yang berbeda. Dalam kegiatan Sabtu religi, saya tanamkan sikap toleransi, saling menghormati, hidup damai, anti radikal dan nilai Islam yang penting ditanamkan dalam konteks Poso yang pernah konflik. ${ }^{25}$

Di samping itu, guru mengintegrasikan nilai multikultural dengan memfungsikan kegiatan sosial yang menjadi sentra perjumpaan antara peserta didik Islam dan Kristen di unit ekstra kurikuler, kerja sosial dan kemanusiaan di sekolah dan masyarakat. Misalnya: kemping lintas agama, paskibraka, porseni, drumband, genre, festival budaya.

Pada kegiatan sosial keagamaan, mereka menunjukkan sikap saling mendukung dan bekerjasama dalam teknik pelaksanaan ibadah atau perayaan hari besar keagamaan umat Islam dan Kristen di sekolah. Pada amal kemanusiaan, peserta didik Islam dan Kristen melakukan aksi simpatik yang didasarkan pada nilai kemanusiaan sebagai sesama makhluk Tuhan.

Integrasi nilai multikultural melalui pendekatan sosialkontekstual banyak berslangsung pada kegiatan ekstra kurikuler, kerja sosial dan amal kemanusiaan peserta didik lintas agama. Pendekatan ini memberikan sumbangan yang lebih nyata dalam mewujudkan perdamaian umat Kristen dan Islam di sekolah daripada penyajian materi di kelas secara formal-tekstual.

\section{3). Kontributif-Kultural}

Pendekatan kontributif-kultural adalah proses integrasi nilai multikultural dalam pembelajaran PAI melalui topik budaya Islam yang termuat dalam silabus, kearifan lokal 'sintuwo maroso',

\footnotetext{
${ }^{25}$ Supartini, W6/S4/GPAI.3/PO/2-3-19.
} 
kegiatan keagamaan yang menjadi kultur keagamaan umat Islam dalam membangun perdamaian umat beragama di sekolah.

Kegiatan keagamaan yang menjadi kultur keagamaan umat Islam dan media pembelajaran informal di sekolah, yaitu: praktik ibadah rutin dan tauziyah, kegiatan Sabtu religi, PHBI, pesantren kilat dan kerja sosial. Kegiatan Sabtu religi dilakukan setiap minggu yang diisi dengan kajian keislaman, praktik keagamaan dan bakti sosial di rumah ibadah agama lain. Pada acara PHBI peserta didik mementaskan sholawat, nasyid, samrah dan tari jepang sebagi media perjumpaan peserta didik Islam dan Kristen yang ikut menyaksikannya.

Pada pendekatan kontributif-kultural ini, guru memasukkan kearifan budaya lokal 'sintuwo maroso' yang mengajarkan hidup bersama dalam perbedaan demi membangun perdamaian di Poso. Meskipun falsafah ini tidak tertulis sebagai muatan materi formal, tetapi guru selalu menyampaikannya dalam pembelajaran di sekolah.

\section{4). Aditif-Tematik}

Pendekatan aditif-tematik merupakan proses integrasi nilai multikultural dalam pembelajaran PAI melalui tema-tema spesifik yang berhubungan dengan perdamaian umat beragama di sekolah dan daerah Poso pasca konflik. Integrasi nilai multikultural dalam pembelajaran melalui pendekatan aditif-tematik berlangsung, baik secara formal-tekstual di kelas maupun secara informal-kontekstual pada kegiatan keagamaan seperti: Sabtu religi, PHBI dan pesantren kilat di islamic center.

Di antara tema-tema tertentu yang diintegrasikan guru dalam pembelajaran di kelas dan kegiatan keagamaan di islamic center meliputi: rekonsiliasi damai, persaudaraan non muslim, nasionalisme dan deradikalisme dan bahaya terorisme yang eksis di daerah Poso. Integrasi nilai multikultural melalui tema-tema tersebut relevan dengan konteks peserta didik yang berada di sekolah, masyarakat dan daerah pasca konflik yang membangun perdamaian umat beragama. Informan berikut menjelaskan:

Selain nilai toleransi, saling menghormati, bekerjasama dan hidup damai dalam perbedaaan, saya juga mengajarkan peserta didik di kelas atau pada kegiatan Sabtu religi tentang resolusi konflik, anti kekerasan kepada yang berbeda, nasionalisme untuk membangun semangat cinta bangsa, bahaya radikalisme beragama 
dan pentingnya memupuk persudaraan antara sesama manusia sebagai ciptaan Tuhan. ${ }^{26}$

Tema-tema tersebut tidak termuat dalam silabus dan tidak pula dibahas menjadi topik tersendiri, tetapi guru mengaitkan dengan materi bercorak multikultural yang relevan dalam silabus. Pada Sabtu religi, PHBI dan pesantren kilat, guru sering mengusung tema persaudaraan, persatuan dan perdamaian untuk membentuk pemahaman dan sikap beragama peserta didik yang damai di tengah komunitas umat Kristen mayoritas.

\section{b. Bentuk Integrasi Nilai Multikultural}

Bentuk integrasi nilai multikultural dalam pembelajaran PAI di SMKN 1 Poso terdiri dari empat jenis, yaitu:

\section{1). Normatif}

Integrasi nilai multikultural dalam pembelajaran PAI pada bentuk normatif berkaitan dengan internalisasi ajaran agama Islam, falsafah Pancasila, nilai kebangsaan dan kearifan budaya lokal masyarakat Poso yang sejalan dengan tujuan PAI dalam membangun perdamaian umat beragama di sekolah dan masyarakat pasca konflik.

Integrasi normatif menjadi salah satu bentuk integrasi formaltekstual, dimana guru mengajarkan peserta didik tentang nilai normativitas Islam yang bersumber dari al-Qur'an dan Hadis seperti dimensi teologis. Integrasi normatif ini berlangsung di dua tempat, yaitu di kelas dan di islamic center. Integrasi nilai multikutural di kelas terikat oleh lingkup materi yang tertuang dalam silabus yang mencakup aspek; teologis, syariah, etika Islam dan sejarah keislaman yang diselaraskan dengan latar historis masyarakat dan daerah Poso yang pernah konflik serta upaya membangun perdamaian.

Sedangakan integrasi nilai multikultural dalam bentuk normatif di islamic center dilakukan melalui praktik keagamaan seperti: pada setiap Sabtu religi, tauziyah, pesantren kilat menjelang bulan Ramadhan, acara buka bersama, dan PHBI untuk menanamkan nilai, norma dan etika sosial agar peserta didik mampu berinteraksi dengan umat agama lain secara damai di sekolah.

\section{2). Interpersonal}


Integrasi nilai multikultural dalam pembelajaran PAI pada bentuk hubungan interpersonal antara peserta didik muslim yang berbeda secara kultural (etnis, daerah, kondisi sosial dan ekonomi) berlangsung di kelas dan kegiatan berbagai keagamaan di islamic center. Kemudian, guru memanfaatkan kegiatan ekstra kurikuler, sosial keagamaan dan amal kemanusiaan sebagai media mengintegrasikan nilai multikultural kepada peserta didik lintas agama agar terbangun hubungan interpersonal yang damai antara peserta didik Islam dan Kristen.

Interaksi interaksi interpersonal antara peserta didik yang berbeda secara kultural dan agama diawali dengan pembentukan karakter personal peserta didik yang baik sebagai basis menjalani hubungan dengan guru dan teman yang berbeda. Dengan karakter personal yang baik akan melahirkan sikap peserta didik yang saling menghormati, peduli, kerjasama dan tidak mudah melakukan tindak kekerasan kepada orang yang berbeda agama di sekolah. Hal ini dijelaskan informan sebagai berikut:

Saya selalu menasehati dan membiasakan kepada setiap siswa muslim untuk saling menjaga ucapan atau lisan dan perbuatannya, agar tidak menyakiti dan menganggu teman yang berbeda agama dan suku. Membiasakan siswa untuk selalu peduli terhadap teman yang sakit dengan cara mengunjunginya, apalagi kalau ada duka, bahkan semua warga sekolah dianjurkan untuk berkunjung. ${ }^{27}$

Dalam interaksi kehidupan sosial, peserta didik muslim minoritas mendapatkan perlakuan yang nyaman dan damai di sekolah. Peserta didik muslimah dapat menggunakan jilbab tanpa intimidasi dan diskriminasi dari guru dan peserta didik Kristen mayoritas. Interaksi interpersonal antara peserta didik Kristen dan Islam di sekolah berjalan harmonis, tidak pernah terjadi perlakuan intoleran apalagi perkelahian yang membawa isu agama dan suku.

\section{3). Sosial}

Integrasi nilai multikultural dalam pembelajaran PAI pada bentuk sosial berlangsung pada kegiatan yang menjadi sentra perjumpaan siswa muslim yang berbeda secara kultural. Mereka menyatu dalam pembelajaran di kelas, ibadah dan sosial keagamaan di islamic center. 
Sedangkan integrasi nilai multikultural pada kehidupan sosial peserta didik Islam dan Kristen berlangsung melalui kegiatan ekstra kurikuler di OSIS, PMR, UKS, pramuka, paskibraka, porseni genre. Peserta didik Kristen dan Islam saling bersinergi melaksanakan aksi sosial (kerja bakti di rumah ibadah dan menghadiri kedukaan) dan mengunjungi warga sekolah yang sakit atau berduka. Peserta didik Kristen dan Islam saling terintegrasi menjadi pengurus organisasi sekolah dan aktif melaksanakan kerja sosial dan kemanusiaan secara bersama-sama, baik umtuk warga sekolah ataupun masyarakat umum.

Peserta didik Kristen dan Islam saling membantu dalam persiapan teknik ibadah dan perayaan hari besar agama lain, bahkan saling menyumbangkan dana untuk kegiatan tersebut. Fakta ini dijelaskan informan sebagai berikut:

Siswa selalu saya dorong untuk saling bekerjasama dalam kegiatan sosial dan kemanusiaan lintas agama walaupun menjadi minoritas di sekolah ini. Siswa Islam dan Kristen saling membantu dalam suka dan duka baik di selama di sekolah, kegiatan keagamaan di sekolah, saling silaturrahim pada momen hari besar keagamaan, bekerjasama dalam kegiatan ekstra kurikuler, menghindari kekerasan pada siapa saja agar tidak memicu benturan dan konflik. Ini semua sebagai bagian praktik pembelajaran PAI di sekolah ini. ${ }^{28}$

Pada integrasi nilai multikultural dalam pembelajaran PAI pada bentuk aksi sosial, guru mendorong peserta didik muslim untuk menyatu bersama peserta didik Kristen dalam berbagai kegiatan akademik dan kehidupan sosial tanpa melihat melihat siapa yang menjadi mayoritas dan minoritas di sekolah. Mereka mampu saling berintegrasi secara sinergis dalam pembelajaran mata pelajaran umum di kelas, kegiatan sosial keagamaan dan amal kemanusiaan.

Peneliti mengamati pembauran kehidupan peserta didik Islam dan Kristen di sekolah terjadi dalam rutinitas kehidupan sehari-hari seperti: belajar bersama di luar kelas, bercanda, bermain, bergandengan, berboncengan motor dan makan bersama di warung sekolah ketika waktu istirhat. ${ }^{29}$

${ }^{28}$ Supartini, W6/S4/GPAI.3/PO/2-3-19.

${ }^{29}$ Observasi Kehidupan Sosial Siswa, O9/Sosial/SMK/8-1-19. 


\section{4). Budaya Lokal}

Integrasi nilai multikultural dalam pembelajaran PAI terkait dengan aktualisasi kearifan lokal masyarakat Poso di sekolah, yaitu: falsafah 'sintuwo maroso' yang mengajarkan hidup damai dalam perbedaan dan budaya 'padungku', yaitu pengungkapan syukur umat Kristen setiap musim panen.

Guru mengintegrasikan kearifan lokal masyarakat Poso, yaitu 'sintawo moroso' sebagai nilai dan prinsip yang dipedomani seluruh warga sekolah dalam kegiatan akademik dan kehidupan sosial untuk membangun perdamaian umat beragama. Integrasi budaya kearifan lokal Poso dalam pembelajaran PAI bertujuan menjaga persatuan dalam menjalani kehidupan bersama dalam perbedaan secara damai.

Dalam praktiknya, integrasi kearifan lokal 'sintawo moroso' menjadi hidden curriculum yang tidak tertulis menjadi muatan silabus PAI, tetapi selalu ditransfer kepada peserta didik. Internalisasi falsafah ini, tidak hanya dilakukan guru PAI pada pembelajaran di kelasnya, tetapi juga melalui kegiatan keagamaan, ekstra kurikuler, kerja sosial dan kemanusiaan antara peserta didik yang berbeda sehingga terbangun kebersamaan dalam membangun perdamaian umat beragama di sekolah.

Integrasi falsafah budaya kearifan lokal 'sintuwo maroso' dalam pembelajaran PAI dijelaskan informan sebagai berikut:

Saya mengaitkan ajaran Islam dengan falsafah Poso sehingga nilai-nilai persatuan terbentuk menjadi karakter siswa dalam hubungan sosial dengan teman yang berbeda. Nilai falsafah 'sintuwo maroso' penting diajarkan dalam pembelajaran PAI sesuai konteks siswa yang berada di sekolah yang pernah konflik agar kebersamaan selalu diutamakan jika ada masalah SARA yang terjadi di sekolah. ${ }^{30}$

Aktualisasi falsafah 'sintawo moroso' di sekolah diwujudkan dalam bentuk menjaga kebersamaan antara peserta didik muslim yang berbeda budaya dalam pembelajaran di kelas dan kegiatan keagamaan di islamic center. Kemudian, peserta didik muslim membangun hubungan yang damai dengan peserta didik Kristen di unit ekstra kurikuler dan kehidupan sosial selama di sekolah.

Setiap pagi, sebelum masuk kelas dan pada upacara bendera hari Senin dilaksanakan doa bersama yang menjadi kultur 
beragama umat Islam dan Kristen di sekolah ini. Setiap selesai idul fitri dan tahun baru diadakan acara jabat tangan antara seluruh warga sekolah untuk saling memberikan maaf memasuki kehidupan yang baru.

\section{SMAN 3 Poso}

Proses integrasi nilai mutikultural dalam pembelajaran PAI di SMAN 3 Poso, baik secara formal-tekstual di kelas maupun secara informal-konstekstual di lingkungan sekolah atau masyarakat meliputi pendekatan dan bentuk integrasi yang diuraikan sebagai berikut:

\section{a. Pendekatan Integrasi Nilai Multikultural}

\section{1). Formal-Tekstual}

Pendekatan formal-tekstual merupakan proses integrasi nilai multikultural dalam pembelajaran PAI berdasarkan karakteristik materi dalam silabus dan berlangsung di kelas. Maka, pendekatan ini sangat terkait dengan KD, IPK dan RPP yang telah didesain guru.

Pada silabus PAI Kurikulum 2013, selai memuat materi teologi, ibadah dan mu'amalat juga memuat secara eskplisit topiktopik yang bercorak multikultural seperti: toleransi, saling menghormati, menjaga persatuan, saling peduli dan kebudayaan Islam.

Pada topik bercorak multikultural, guru mengintegrasikan nilai multikultural dengan KD dan IPK hasil belajar yang akan dicapai peserta didik secara langsung. Sedangkan pada materi yang tidak bercorak multikultural seperti: akidah, ayat al-Qur'an dan Hadis, sholat jenazah, haji, puasa, zakat, jual beli, pernikahan dan faraid, guru menarik pesan substantif yang sejalan dengan realitas keragaman peserta didik dan upaya membangun perdamaian umat beragama.

Guru mengintegrasikan nilai multikultural dalam pembelajaran formal di kelas, baik secara langsung maupun tidak langsung dengan mengacu pada muatan materi PAI dalam silabus Kurikulum 2013. Terkait pendekatan ini, informan menjelaskan:

Materi tidak ditulis secara leterlek, tetapi sangat konteks dengan realitas sekolah dan daerah Poso yang plural, misalnya dalam materi asmaul husna, materi tentang Allah Maha Pemberi Keamanan. Sifat Allah ini harus diterapkan dalam kehidupan dengan orang atau masyarakat yang berbeda agama dan budaya. Materi yang tidak ditulis langsung tentang toleransi saya kaitkan dengan realitas siswa dan daerah Poso. Saya 
menonjolkan aspek sosial dan kemanusiaan terhadap yang berbeda sesuai nilai-nilai universal Islam, bukan masalah perbedaan teologi. Saya ingin menampilkan Islam yang toleran dan humanis terhadap perbedaan agama. $^{31}$

Integrasi nilai multikultural dalam pembelajaran PAI dengan pendekatan formal-tekstual sangat terikat dengan karakteristik materi dalam silabus, KD dan IPK hasil belajar yang akan dicapai peserta didik. Di samping itu, pendekatan ini berkaitan dengan implementasi RPP PAI yang telah didesain guru dari tahap penyajian materi bermuatan nilai multikultural sampai penilaian hasil belajar secara formal di kelas.

\section{2). Sosial-Kontekstual}

Pada pendekatan sosial-kontekstual adalah proses integrasi nilai multikultural dalam pembelajaran PAI dengan mengaitkan materi sesuai realitas sosial peserta didik yang majemuk, umat Kristen minoritas, masyarakat yang pernah konflik dan upaya membangun perdamaian.

Guru mengintegrasikan nilai multikultural melalui kegiatan keagamaan sebagai sentra kegiatan peserta didik muslim yang berbeda secara kultural seperti: di masjid sekolah, PHBI, rohis dan pesantren kilat. Kemudian, guru memanfaatkan kegiatan ekstra kurikuler, kerja sosial dan amal kemanusiaan sebagai ruang perjumpaan peserta didik Islam dan Kristen dalam membangun perdamaian di sekolah.

Masjid Nurul Haq menjadi salah laboratorium sosial bagi peserta didik muslim yang berbeda secara kultural. Pelaksanaan praktik ritual ibadah dipusatkan di masjid. Sementara kegiatan sosial keagamaan seperti PHBI di lapangan dan pesantren kilat di aula sekolah agar dapat menampung peserta didik muslim yang mayoritas.

Pada setiap Jum'at religi minggu ke empat diisi ceramah agama yang mendukung perdamaian umat beragama di sekolah dengan mengundang da'i dari luar sekolah. Fakta ini diungkapkan informan berikut ini: "Minggu ke 4 untuk ceramah agama bagi umat Islam. Pada Jumat religi, kami mengundang penceramah muslim yang moderat agar dapat menyejukkan kondisi keragaman

${ }^{31}$ Suardi, W16/S4/GPAI.1/PO/15-12-18. 
siswa dan guru yang berbeda di sekolah ini." 32 Sedangan PHBI biasa dilaksanakan di lapangan dan pesantren kilat di aula sekolah.

Selain itu, kegiatan keagamaan dilaksanakan melalui unit rohis Islam dengan kajian mingguan setiap Senin sore seputar tema-tema hukum Islam dan etika sosial. Terkadang peserta didik mengundang narasumber dari luar menyampaikan kajian keislaman dalam membangun kehidupan damai di tengah keragaman warga sekolah.

Realitas di atas dijelaskan informan berikut: "Kami ikut kegiatan di pramuka dan rohis. Pada kegiatan rohis setiap sore Senin, kami mengundang pemateri dari luar sekolah. Kami membahas tentang ke-islam-an dan membaca Qur'an, fiqih wanita dan cara beretika dengan orang lain yang berbeda agama dan etnis." 33

Melalui kegiatan keagamaan, peserta didik muslim yang berbeda secara kultural saling membaur, berbagi dan bekerjasama secara sinergis dari sejak persiapan hingga selesainya acara, bahkan pada PHBI yang mengusung tema-tema seputar toleransi, persatuan, hidup damai dan persaudaraan sesama manusia selalu diikuti oleh peserta didik Kristen.

Sedangkan kegiatan yang menjadi sentra perjumpaan peserta didik muslim dan Kristen adalah unit ekstra kurikuler (OSIS, PMR, pramuka dan porseni), kerja sosial dan amal kemanusiaan di sekolah. Guru memfungsikan sejumlah kegiatan perdamaian yang pernah dilaksanakan di sekolah seperti dialog perdamaian oleh Syafi'i Ma'arif Institut sebagai media mengintegrasikan nilai multikultural kepada peserta didik.

\section{3). Kontributif-Kultural}

Pendekatan kontributif-kultural adalah proses pengintegrasian nilai multikultural dalam pembelajaran PAI melalui topik materi kebudayaan Islam, kultur keragamaan umat Islam dan kearifan lokal masyarakat Poso. Dalam silabus memuat beberapa topik bercorak multikultural yang berhubungan dengan kebudayaan Islam, seperti: sejarah dakwah Rasulullah Saw, masa kejayaan Islam, perkembangan Islam di Indonesia secara damai di masyarakat majemuk. Kehidupan damai antarumat Islam, Yahudi dan Kristen di Negara Madinah dan perlindungan sahabat Umar bin

\footnotetext{
${ }^{32}$ I Putu Sudarma, W14/S2/Wakur/PO/12-4-19.

${ }^{33}$ Rifaldi Ayuba, W19/S5/ SI.X-1/PO/6-4-19.
} 
Khattab atas jiwa, harta benda dan gereja umat Nasrani di Palestina.

Guru mengintegrasikan nilai multikultural melalui kegiatan keagamaan yang menjadi kultur beragama umat Islam di SMAN 3 Poso, yaitu: sholat berjama'ah dan kultum setiap hari, Jum'at religi dan aksi amal setiap bulan, PHBI, rohis setiap Senin sore, latihan pidato PAI, pesantren kilat setiap bulan Ramadhan, halal bi halal setelah idul fitri, penyaluran sembako ke panti asuhan dan pemotongan hewan kurban ke masyarakat sekitar sekolah setiap tahun.

Terkait kegiatan latihan pidato PAI, umat Islam banyak mengusung tema tentang toleransi dan perdamaian antarumat beragama. Tahun 2019, peserta didik SMAN 3 berhasil menjuarai lomba pidato PAI terkait perdamaian umat beragama di tingkat provinsi yang dilaksanakan oleh Kementerian Agama Provinsi Sulawesi Tengah dan mewakili ke tingkat nasional di Jakarta. ${ }^{34}$

Pada aspek budaya, guru mengitegrasikan nilai multikultural melalui praktik kearifan lokal masyarakat Poso, yaitu 'sintuwo maroso' yang relevan dengan ajaran Islam dan kebutuhan membangun perdamaian umat beragama di sekolah dan daerah Poso pasca konflik.

\section{4). Aditif-Tematik}

Pendekatan aditif-tematik adalah proses pengintegrasian nilai multikultural melalui tema-tema tertentu yang relevan dengan upaya membangun perdamaian umat beragama di daerah Poso pasca konflik. Tema-tema tertentu meliputi: resolusi konflik, rekonsiliasi damai, dialog umat beragama, persaudaraan non muslim, nasionalisme, deradikalisme dan bahaya terorisme.

Integrasi nilai multikultural dalam pembelajaran PAI melalui tema-tema perdamaian, baik di kelas ataupun pada kegiatan keagamaan di sekolah untuk mengembangkan wawasan peserta didik tentang isu-isu nasional dan global yang berkaitan dengan perdamaian umat beragama. Selain itu, pendekatan aditif-tematik bertujuan mencari titik temu dalam membangun perdamaian umat beragama di sekolah dan daerah Poso.

Integrasi nilai multikultural melalui tema-tema spesifik ini tidak dibahas menjadi topik tersendiri, tetapi diintegrasikan dengan materi yang bermuatan nilai multikultural yang relevan dalam silabus. Pada kegiatan keagamaan di sekolah, tema-tema spesifik

\footnotetext{
${ }^{34}$ Dokumen Sekolah, D3/D.1/Kondisi/SMA/24-5-19.
} 
ini sering dijadikan topik pada acara PHBI yang sering dihadiri peserta didik Kristen sebagai wujud komitmen kebersamaan mereka membangun perdamaian umat beragama di sekolah.

\section{b. Bentuk Integrasi Nilai Multikultural}

Bentuk integrasi nilai multikultural dalam pembelajaran PAI di SMAN 3 Poso meliputi empat, yaitu:

\section{1). Normatif}

Integrasi nilai multikultural dalam pembelajaran PAI pada bentuk normatif berkaitan dengan penanaman nilai ajaran agama Islam, falsafah bangsa, dan kearifan budaya masyarakat Poso untuk membangun sikap beragama peserta didik muslim yang damai, baik secara internal maupun eksternal dengan peserta didik Kristen minoritas selama mengikuti pembelajaran di kelas dan kehidupan sosial di sekolah.

Integrasi nilai multikultural dalam pembelajaran PAI dalam bentuk normativitas ajaran Islam, baik pada dimensi spritual maupun kehidupan sosial menjadi muatan yang paling banyak dalam silabus PAI.

Sedangkan integrasi nilai multikultural yang berkaitan dengan falsafah bangsa, nasionalisme dan kearifan budaya lokal dikaitkan dengan materi bercorak multikultural yang termuat dalam silabus seperti: saling menghormati, menolong dan menjaga persatuan. Informan menjelaskan:

Saya mengintegrasikan nilai dan budaya multikultural dalam PAI merujuk pada ajaran al-Quran, Hadist, Ijma, dan Shiroh sahabat yang mengajarkan sikap hormat pada perbedaan. Seperti sejarah berdiri bangsa Indonesia didukung semua umat beragama dari suku dan daerah yang berbeda saya ajarkan pada siswa melalui topik yang relevan di silabus." ${ }^{35}$

Pada materi yang bermuatan nilai multikultural, guru langsung menginternalisasikan kepada peserta didik sesuai kompetensi dasar dan tujuan pembelajaran bercorak multikultural yang mendukung perdamaian umat beragama di sekolah. Sedangkan pada topik materi tentang ritual ibadah yang tidak bercorak multikultural, guru menarik nilai esensi yang sejalan dengan prinsip multikultural yang dapat diterapkan dalam kehidupan sosial lintas agama di sekolah dan masyarakat.

${ }^{35}$ Suardi, W16/S4/GPAI.1/PO/15-12-18. 
Baik pada materi yang langsung bercorak multikultural ataupun yang tidak seperti: akidah, ibadah dan mua'malat samasama mengandung nilai normatif yang mengajarkan sikap hidup yang damai dalam menyikapi segala perbedaan yang dimiliki umat manusia.

\section{2). Interpersonal}

Integrasi nilai multikultural dalam pembelajaran PAI pada bentuk hubungan interpersonal antara peserta didik muslim yang berbeda secara kultural berlangsung di kelas, praktik ibadah di masjid dan kegiatan sosial keagamaan di sekolah. Sedangkan hubungan interreligius dengan peserta didik Kristen berlangsung pada kegiatan ekstra kurikuler, sosial keagamaan dan aksi amal kemanusiaan.

Integrasi nilai multikultural dalam pembelajaran PAI sebagai upaya guru menginternalisasikan nilai, etika, akhlak mulia dan norma budaya dalam upaya membentuk karakter personal peserta didik muslim sebagai pijakan menjalani kehidupan sosial lintas budaya dan agama di sekolah.

Karakter personal peserta didik muslim dalam menjalin hubungan lintas agama dengan peserta didik Kristen minoritas di sekolah, yaitu: sikap jujur, amanah, sabar, tanggungjawab, santun, kasih sayang, ramah dan peduli kepada siapapun yang berbeda dengan dirinya. Terkait sikap personal ini, informan berikut menjelaskan:

Dengan mengacu pada kompetensi inti yang memuat kompetensi spritual dan sosial. Saya menanamkan pada siswa sikap yang sejalan dengan akhlakul karimah, seperti: jujur, sabar, amanah, santun dan penyanyang. Pada sikap sosial, saya tanamkan pada siswa tentang: saling menghormati, toleransi, saling peduli, saling bekerjasama dan damai kepada siapasaja tanpa memandang perbedaan agama dan etnis di antara mereka. ${ }^{36}$

Integrasi antara peserta didik muslim yang berbeda secara kultural dalam pembelajaran di kelas dan kegiatan keagamaan di sekolah ditunjukkan dengan sikap saling menghormati perbedaan etnis, mengunjungi teman yang sakit, bekerjasama dalam menyelesaikan tugas kelompok, beretika yang sopan pada teman 
berbeda gender dan saling menjaga dari aksi kekerasan sehingga mendukung terciptanya perdamaian umat beragama di sekolah.

Sedangkan interaksi lintas agama antara peserta didik Islam dan Kristen berlangsung pada kegiatan di unit ekstra kurikuler, kerja sosial dan kemanusiaan sebagai ruang perjumpaan segala perbedaan yang mereka miliki di sekolah. Guru memanfaatkan organisasi kesiswaan seperti: OSIS, pramuka, dan porseni untuk memupuk hubungan antara peserta didik yang berbeda agama sehingga mendukung perdamaian umat beragama di sekolah ini.

Fenomena menarik dari integrasi nilai multikultural dalam pembelajaran PAI pada bentuk hubungan interpersonal antara peserta didik yang berbeda di SMAN 3 Poso adalah peserta didik Kristen tanpa paksaan mengikuti pembelajaran PAI di kelas. Mereka menjalin interaksi edukatif dengan peserta didik muslim melalui sesi tanya jawab tentang ajaran agama masing-masing yang terkait dengan sikap sosial dan kemanusiaan.

Fakta hubungan interpersonal antara peserta didik Islam dan Kristen dalam pembelajaran diungkapkan informan sebagai berikut: "Di kelas saya, sering siswa Kristen ikut belajar PAI tanpa paksaan. Saya berikan kesempatan mereka untuk bertanya dan menjawab pertanyaan yang berhubungan dengan sikap hidup antarumat beragama yang berbeda." 37 Selain itu, integrasi nilai multikultural dalam pembelajaran PAI pada bentuk hubungan interpersonal antara peserta didik Islam dan Kristen dengan melakukan dialog lintas agama tentang masalah sosial dan kemanusiaan dalam membangun harmoni kehidupan umat beragama.

\section{3). Sosial}

Integrasi nilai multikultural dalam pembelajaran PAI pada bentuk kehidupan sosial menjadi kegiatan yang paling banyak dilakukan guru PAI, baik pada pembelajaran di kelas, kegiatan keagamaan dan interaksi kehidupan di sekolah. Pada pembelajaran di kelas dan kegiatan keagamaan di masjid, peserta didik muslim yang berbeda secara kultural saling berinteraksi secara rukun selama mengikuti kegiatan pembelajaran dan ibadah. Di lingkungan sekolah, peserta didik Islam dan Kristen terintegrasi secara harmonis dengan saling membaur, berteman dan bekerjasama dalam berbagai kegiatan ekstra kurikuler, kerja sosial dan penggalangan amal kemanusiaan.

${ }^{37}$ Fitri S.Tahir, W18/S4/GPAI.3/PO/29-4-19. 
Guru selalu mendorong peserta didik Islam mayoritas dan Kristen minoritas saling berintegrasi dalam kehidupan sosial dengan saling menerima perbedaan etnis, agama, praktik ritual ibadah secara damai. Guru menyatukan peserta didik Islam dan Kristen melalui berbagai kegiatan ekstra kurikuler, kerja sosial keagamaan, amal kemanusiaan dan program perdamaian yang pernah dilaksanakan di sekolah.

Integrasi nilai multikultural dalam bentuk sosial berlangsung pada kerja sosial dan kemanusiaan lintas agama di luar kelas. Di antara bentuk kerja sosial yang menjadi sentra perjumpaan peserta didik Islam dan Kristen, yaitu: bakti sosial di masjid, gereja dan pura di sekitar Kota Poso, saling membantu kegiatan sosial keagamaan, menggalang dana sakit, duka, bencana dan pengumpulan sembako untuk panti asuhan.

\section{4). Budaya Lokal}

Integrasi nilai multikultural dalam pembelajaran PAI pada bentuk kearifan budaya lokal, guru mengintegrasikan falsafah masyarakat Poso, yaitu 'sintuwo maroso' yang mengajarkan hidup bersama dalam perbedaaan. Integrasi kearifan lokal ini dilakukan melalui pembelajaran di kelas, kegiatan keagamaan di masjid, esktra kurikuler, kerja sosial dan kemanusiaan di sekolah.

Terkait realitas tersebut, informan berikut mengungkapkan: "Saya sering menyampaikan nilai falsafah Poso yaitu; 'sintuwo maroso' ketika pembelajaran PAI di kelas atau kegiatan keagamaan di masjid dan kegiatan sosial untuk menguatkan kebersamaan peserta didik di sekolah agar menjadi karakter hidup yang dibawa ke rumah dan masyarakat Poso." 38

Integrasi budaya kearifan lokal 'sintuwo maroso' sebagai hindden integration, yang tidak termuat secara formal-tekstual dalam silabus PAI, tetapi selalu diinternalisasikan pada peserta didik dalam pembelajaran, kegiatan keagamaan, ekstra kurikuler, aksi sosial dan amal kemanusiaan untuk meneguhkan kebersamaan dan persatuan semua peserta didik Islam dan Kristen dalam membangun perdamaian umat beragama di sekolah.

Pendekatan dan bentuk integrasi nilai multikultural dalam pembelajaran PAI di kedua sekolah pasca konflik di atas dapat diringkas seperti dalam tabel berikut:

\begin{tabular}{|l|l|l|l|l|}
\hline No & Pendekatan & SMKN 1 & SMAN 3 & Temuan Lintas Situs \\
\hline
\end{tabular}

${ }^{38}$ Nurminah, W17/S4/ GPAI.1/PO/12-4-19. 


\begin{tabular}{|c|c|c|c|c|}
\hline & Integrasi & & & \\
\hline 1. & $\begin{array}{l}\text { Formal- } \\
\text { Tekstual }\end{array}$ & $\begin{array}{l}\text { - Berdasar } \\
\text { kan } \\
\text { karakteri } \\
\text { stik } \\
\text { materi } \\
\text { dalam } \\
\text { silabus. } \\
\text { - Terikat } \\
\text { KI, KD, } \\
\text { IPK dan } \\
\text { RPP. } \\
\text { - Pembela } \\
\text { jaran di } \\
\text { kelas. } \\
\text { - Integrasi } \\
\text { langsung } \\
\text { dan } \\
\text { tidak } \\
\text { langsung }\end{array}$ & $\begin{array}{l}\text { - Berdasarkan } \\
\text { karakteristik } \\
\text { materi dalam } \\
\text { silabus. } \\
\text { - Terikat KI, } \\
\text { KD, IPK dan } \\
\text { RPP. } \\
\text { - Pembelajaran } \\
\text { di kelas. } \\
\text { - Integrasi } \\
\text { langsung dan } \\
\text { tidak } \\
\text { langsung. }\end{array}$ & $\begin{array}{l}\text { - Integrasi nilai } \\
\text { multikultural } \\
\text { secara formal- } \\
\text { tekstual di kedua } \\
\text { situs memiliki } \\
\text { kriteria dan proses } \\
\text { yang sama. } \\
\text { - Integrasi langsung } \\
\text { pada materi } \\
\text { bercorak } \\
\text { multikultural dan } \\
\text { integrasi tidak } \\
\text { langsung pada } \\
\text { materi tekait } \\
\text { teologi, ibadah, } \\
\text { mu'amalat } \\
\text { dilaksanakan di } \\
\text { kedua situs. }\end{array}$ \\
\hline 2. & $\begin{array}{l}\text { Sosial- } \\
\text { Kontekstual }\end{array}$ & $\begin{array}{l}\text { - Relevans } \\
\text { i materi } \\
\text { dengan } \\
\text { realitas } \\
\text { sosial } \\
\text { siswa. } \\
\text { - Pembela } \\
\text { jaran di } \\
\text { kelas } \\
\text { - Sentra } \\
\text { keagama } \\
\text { an di } \\
\text { islamic } \\
\text { center. } \\
\text { - Nilai, } \\
\text { etika dan } \\
\text { kerja } \\
\text { sosial. } \\
\text { - Lintas } \\
\text { budaya } \\
\end{array}$ & $\begin{array}{l}\text { - Relevansi } \\
\text { materi dengan } \\
\text { realitas sosial } \\
\text { siswa. } \\
\text { - Pembelajaran } \\
\text { di kelas. } \\
\text { - Sentra } \\
\text { keagamaan di } \\
\text { masjid Nurul } \\
\text { Haq dan } \\
\text { lapangan. } \\
\text { - Nilai, etika } \\
\text { dan kerja } \\
\text { sosial. } \\
\text { - Lintas budaya } \\
\text { dan agama. } \\
\text { - Langsung dan } \\
\text { tidak } \\
\text { langsung. }\end{array}$ & $\begin{array}{l}\text { - Di kedua situs, } \\
\text { guru } \\
\text { mengintegrasikan } \\
\text { nilai multikultural } \\
\text { dengan } \\
\text { memperhatikan } \\
\text { realitas sosial } \\
\text { keragaman siswa, } \\
\text { masyarakat pasca } \\
\text { konflik dan upaya } \\
\text { membangun } \\
\text { perdamaian umat } \\
\text { beragama. } \\
\text { - Integrasi nilai } \\
\text { multikultural } \\
\text { secara informal } \\
\text { dilakukan pada } \\
\text { sentra sosial siswa } \\
\text { muslim lintas } \\
\text { budaya atau } \\
\end{array}$ \\
\hline
\end{tabular}




\begin{tabular}{|c|c|c|c|c|}
\hline & & $\begin{array}{l}\text { dan } \\
\text { agama. } \\
\text { - Langsun } \\
\text { g dan } \\
\text { tidak } \\
\text { langsung }\end{array}$ & & $\begin{array}{l}\text { dengan siswa } \\
\text { Kristen. }\end{array}$ \\
\hline 3. & $\begin{array}{l}\text { Kontributif- } \\
\text { Kultural }\end{array}$ & $\begin{array}{l}\text { - Topik } \\
\text { budaya } \\
\text { Islam di } \\
\text { silabus. } \\
\text { - Kultur } \\
\text { keagama } \\
\text { an umat } \\
\text { Islam } \\
\text { tidak } \\
\text { marak. } \\
\text { - Kearifan } \\
\text { lokal } \\
\text { 'sintuwo } \\
\text { maroso' } \\
\text { - Pembela } \\
\text { jaran di } \\
\text { kelas } \\
\text { dan di } \\
\text { islamic } \\
\text { center. } \\
\text { - Langsun } \\
\text { g dan } \\
\text { tidak } \\
\text { langsung }\end{array}$ & $\begin{array}{l}\text { - Topik budaya } \\
\text { Islam di } \\
\text { silabus. } \\
\text { - Kultur } \\
\text { keagamaan } \\
\text { umat Islam } \\
\text { marak. } \\
\text { - Kearifan lokal } \\
\text { 'sintuwo } \\
\text { maroso' } \\
\text { - Pembelajaran } \\
\text { di kelas dan di } \\
\text { masjid dan } \\
\text { lapangan } \\
\text { sekolah. } \\
\text { - Langsung dan } \\
\text { tidak } \\
\text { langsung. }\end{array}$ & $\begin{array}{l}\text { - Kedua situs } \\
\text { mengintegrasikan } \\
\text { nilai multikultural } \\
\text { melalui topik } \\
\text { kebudayaan Islam } \\
\text { secara langsung di } \\
\text { kelas. } \\
\text { - Kegiatan } \\
\text { keagamaan yang } \\
\text { menjadi kultur } \\
\text { umat Islam di situs } \\
\text { I tidak sama } \\
\text { maraknya dengan } \\
\text { di situs II sehingga } \\
\text { berdampak pada } \\
\text { optimalisasi } \\
\text { integrasi nilai } \\
\text { multikultural di } \\
\text { masing-masing } \\
\text { situs. }\end{array}$ \\
\hline 4. & $\begin{array}{l}\text { Aditif- } \\
\text { Tematik }\end{array}$ & $\begin{array}{l}\text { - Menamb } \\
\text { ahkan } \\
\text { tema } \\
\text { perdama } \\
\text { ian: } \\
\text { persauda } \\
\text { raan non } \\
\text { muslim, } \\
\text { bahaya }\end{array}$ & $\begin{array}{l}\text { - Menambahkan } \\
\text { tema } \\
\text { perdamaian: } \\
\text { dialog umat } \\
\text { beragama, } \\
\text { persudaraan } \\
\text { non muslim, } \\
\text { deradikalisme. } \\
\text { - Tidak termuat }\end{array}$ & $\begin{array}{l}\text { - Integrasi nilai } \\
\text { multikultural di } \\
\text { kedua situs } \\
\text { dilakukan dengan } \\
\text { menambahkan } \\
\text { tema-tema } \\
\text { perdamaian sesuai } \\
\text { konteks daerah } \\
\text { Poso yang pernah }\end{array}$ \\
\hline
\end{tabular}




\begin{tabular}{|c|c|c|c|c|}
\hline & & $\begin{array}{l}\text { terorism } \\
\text { e. } \\
\text { - Tidak } \\
\text { termuat } \\
\text { dalam } \\
\text { silabus. } \\
\text { - Pembela } \\
\text { jaran di } \\
\text { kelas. } \\
\text { - PHBI } \\
\text { dan } \\
\text { pesantre } \\
\text { n kilat di } \\
\text { islamic } \\
\text { center. } \\
\text { - Langsun } \\
\text { g dan } \\
\text { tidak } \\
\text { langsung } \\
\text {. }\end{array}$ & $\begin{array}{l}\text { dalam silabus. } \\
\text { - Pembelajaran } \\
\text { di kelas. } \\
\text { - PHBI, } \\
\text { pesantren } \\
\text { kilat, pidato } \\
\text { PAI. } \\
\text { - Langsung dan } \\
\text { tidak } \\
\text { langsung. }\end{array}$ & $\begin{array}{l}\text { mengalami konflik } \\
\text { sosial. } \\
\text { - Di situs II, siswa } \\
\text { melakukan dialog } \\
\text { lintas agama } \\
\text { mancari titik temu } \\
\text { dalam kehidupan } \\
\text { sosial yang tidak } \\
\text { ada pada situs I. }\end{array}$ \\
\hline & $\begin{array}{l}\text { Bentuk } \\
\text { Integrasi }\end{array}$ & & & \\
\hline 1. & Normatif & $\begin{array}{l}\text { - Nilai } \\
\text { ajaran } \\
\text { Islam } \\
\text { - Falsafah } \\
\text { Pancasil } \\
\text { a } \\
\text { - Atribut } \\
\text { kebangs } \\
\text { aan } \\
\text { - Kearifan } \\
\text { lokal } \\
\text { Poso. } \\
\text { - Pembela } \\
\text { jaran di } \\
\text { kelas } \\
\text { dan } \\
\text { kegiatan } \\
\text { keagama } \\
\text { an di }\end{array}$ & $\begin{array}{l}\text { - Nilai ajaran } \\
\text { Islam } \\
\text { - Falsafah } \\
\text { Pancasila } \\
\text { - Atribut } \\
\text { kebangsaan } \\
\text { - Kearifan lokal } \\
\text { Poso. } \\
\text { - Pembelajaran } \\
\text { di kelas dan } \\
\text { kegiatan } \\
\text { keagamaan di } \\
\text { masjid. }\end{array}$ & $\begin{array}{l}\text { - Integrasi nilai } \\
\text { multikultural pada } \\
\text { bentuk normatif } \\
\text { memiliki muatan } \\
\text { dan cakupan yang } \\
\text { sama di kedua } \\
\text { situs. } \\
\text { - Kedua situs } \\
\text { menekankan } \\
\text { integrasi nilai } \\
\text { nasionalisme } \\
\text { melalui materi } \\
\text { dalam silabus } \\
\text { sesuai konteks } \\
\text { daerah Poso yang } \\
\text { masih rawan } \\
\text { paham } \\
\text { radikalisme. }\end{array}$ \\
\hline
\end{tabular}




\begin{tabular}{|c|c|c|c|c|}
\hline & & $\begin{array}{l}\text { islamic } \\
\text { center. }\end{array}$ & & \\
\hline 2. & $\begin{array}{l}\text { Inter- } \\
\text { personal }\end{array}$ & $\begin{array}{l}\text { - Siswa } \\
\text { muslim } \\
\text { lintas } \\
\text { budaya. } \\
\text { - Pembela } \\
\text { jaran di } \\
\text { kelas } \\
\text { dan } \\
\text { kegiatan } \\
\text { keagama } \\
\text { an di } \\
\text { islamic } \\
\text { center. } \\
\text { - Siswa } \\
\text { Islam } \\
\text { dan } \\
\text { Kristen } \\
\text { di } \\
\text { kegiatan } \\
\text { ekstra } \\
\text { kurikuler } \\
\text {, kerja } \\
\text { sosial } \\
\text { dan } \\
\text { kemanus } \\
\text { iaan. }\end{array}$ & $\begin{array}{l}\text { - Siswa muslim } \\
\text { lintas budaya. } \\
\text { - Pembelajaran } \\
\text { di kelas dan } \\
\text { kegiatan } \\
\text { keagamaan di } \\
\text { masjid. } \\
\text { - Siswa Islam } \\
\text { dan Kristen di } \\
\text { kegiatan ekstra } \\
\text { kurikuler, } \\
\text { kerja sosial } \\
\text { dan } \\
\text { kemanusiaan. } \\
\text { - Siswa Kristen } \\
\text { mengikuti } \\
\text { materi PAI di } \\
\text { kelas tanpa } \\
\text { paksaan. }\end{array}$ & $\begin{array}{l}\text { - Integrasi nilai } \\
\text { multikultural pada } \\
\text { bentuk } \\
\text { interpesonal antara } \\
\text { siswa muslim yang } \\
\text { berbeda budaya } \\
\text { atau dengan siswa } \\
\text { Kristen dalam } \\
\text { membangun } \\
\text { perdamaian } \\
\text { berlangsung di } \\
\text { kedua situs. } \\
\text { - Di situs I tidak } \\
\text { ditemukan ada } \\
\text { siswa Kristen yang } \\
\text { mengikuti materi } \\
\text { PAI di kelas } \\
\text { seperti di situs II. }\end{array}$ \\
\hline 3. & Sosial & $\begin{array}{l}\text { - Kegiatan } \\
\text { sosial } \\
\text { keagama } \\
\text { an pada } \\
\text { Sabtu } \\
\text { religi } \\
\text { dan } \\
\text { PHBI. } \\
\text { - Kerja } \\
\text { bakti di } \\
\text { rumah } \\
\text { ibadah. } \\
\text { - Menggal }\end{array}$ & $\begin{array}{l}\text { - Kegiatan } \\
\text { sosial } \\
\text { keagamaan } \\
\text { pada Jum'at } \\
\text { religi dan } \\
\text { PHBI. } \\
\text { - Kerja bakti di } \\
\text { rumah ibadah. } \\
\text { - Menggalang } \\
\text { dana } \\
\text { kemanusiaan. } \\
\text { - Membesuk } \\
\text { yang sakit } \\
\end{array}$ & $\begin{array}{l}\text { - Integrasi nilai } \\
\text { multikultural pada } \\
\text { bentuk sosial di } \\
\text { kedua situs } \\
\text { dominan dilakukan } \\
\text { di luar kelas } \\
\text { melalui kegiatan } \\
\text { sosial keagamaan } \\
\text { dan kemanusiaan } \\
\text { di } \\
\text { sekolah/masyaraka } \\
\text { t. } \\
\text { - Di situs I, pada }\end{array}$ \\
\hline
\end{tabular}




\begin{tabular}{|c|c|c|c|c|}
\hline & & $\begin{array}{l}\text { ang dana } \\
\text { kemanus } \\
\text { iaan. } \\
\text { - Membes } \\
\text { uk yang } \\
\text { sakit. } \\
\text { - Melayat } \\
\text { ke } \\
\text { komunit } \\
\text { as Islam. } \\
\text { - Berkunj } \\
\text { ung pada } \\
\text { hari raya } \\
\text { idul fitri } \\
\text { dan } \\
\text { natal. } \\
\text { - Menyiap } \\
\text { kan } \\
\text { menu } \\
\text { makanan } \\
\text { halal } \\
\text { menurut } \\
\text { Islam. }\end{array}$ & $\begin{array}{l}\text { - Melayat ke } \\
\text { komunitas } \\
\text { Kristen. } \\
\text { - Mengumpulka } \\
\text { n sembako } \\
\text { - Pembagian } \\
\text { daging hewan } \\
\text { kurban. }\end{array}$ & $\begin{array}{l}\text { perayaan natal di } \\
\text { sekolah, open } \\
\text { house dan acara } \\
\text { 'padungku' } \\
\text { mengundang umat } \\
\text { Islam dengan } \\
\text { menyiapkan } \\
\text { makanan halal } \\
\text { menurut syari' at } \\
\text { Islam sebagai } \\
\text { pembeda dari situs } \\
\text { II. }\end{array}$ \\
\hline 4. & $\begin{array}{l}\text { Budaya } \\
\text { Lokal }\end{array}$ & $\begin{array}{l}\text { - Kearifan } \\
\text { lokal } \\
\text { Poso, } \\
\text { 'sintuwo } \\
\text { maroso' } \\
\text { dan } \\
\text { 'padung } \\
\text { ku'. } \\
\text { - Pembela } \\
\text { jaran di } \\
\text { kelas } \\
\text { dan } \\
\text { kehidupa } \\
\text { n sosial } \\
\text { di } \\
\text { sekolah. }\end{array}$ & $\begin{array}{l}\text { - Kearifan lokal } \\
\text { Poso, 'sintuwo } \\
\text { maroso'. } \\
\text { - Pembelajaran } \\
\text { di kelas dan } \\
\text { kehidupan } \\
\text { sosial di } \\
\text { sekolah. }\end{array}$ & $\begin{array}{l}\text { - Integrasi nilai } \\
\text { multikultural pada } \\
\text { bentuk budaya } \\
\text { lokal dilakukan } \\
\text { melalui aktualisasi } \\
\text { kearifan 'sintuwo } \\
\text { maroso' } \\
\text { berlangsung di } \\
\text { kedua situs. } \\
\text { - Guru di situs I } \\
\text { mengintegrasikan } \\
\text { nilai multikultural } \\
\text { melalui kearifan } \\
\text { 'padungku' untuk } \\
\text { menghormati } \\
\text { budaya umat } \\
\text { Kristen mayoritas } \\
\text { yang tidak }\end{array}$ \\
\hline
\end{tabular}




\begin{tabular}{|l|l|l|l|}
\hline & & & $\begin{array}{l}\text { dilakukan pada } \\
\text { situs II. }\end{array}$ \\
\hline
\end{tabular}

\section{E. Pembahasan Temuan Hasil Penelitian}

\section{Pendekatan Integrasi Nilai Multikultural dalam PAI}

Pembahasan tentang pendekatan integrasi nilai multikultural dalam pembelajaran PAI di kedua sekolah pasca konflik merujuk pada temuan penelitian lintas situs di atas yang diuraikan sebagai berikut:

\section{a. Formal-Tekstual}

Temuan penelitian di kedua situs memperlihatkan bahwa integrasi nilai multikultural dalam pembelajaran PAI dengan pendekatan formal-tekstual memiliki kriteria dan cakupan yang sama. Pendekatan ini dilakukan berdasarkan karakteristik materi yang termuat dalam silabus, apakah bercorak multikultural atau tidak. Karena itu, pendekatan ini sangat terikat dengan KI, KD, IPK, pelaksanaan RPP yang dirancang guru dan dominan berlangsung pada pembelajaran secara formal di kelas.

Dalam praksis pendidikan nasional di Indonesia, integrasi nilai multikultural melalui pendekatan formal-tekstual berkaitan erat dengan implementasi kurikulum PAI di sekolah umum yang bersifat sentralistik. Pembakuan nilai universal dan tema kebudayaan Islam yang kontekstual dalam silabus dipahami sebagai upaya membentuk karakater beragama peserta didik yang sesuai dengan identitas bangsa Indonesia. Sehingga muatan materi PAI tidak menjadi antitesa terhadap ideologi Pancasila, UUD 1945 dan atribut kebangsaan.

Berdasarkan muatan materi dalam silabus pelajaran PAI dan Budi Pekerti Kurikulum 2013 tingkat SMA/SMK yang berlaku secara nasional, Rahman dkk menjelaskan bahwa integrasi nilai multikultural dalam pembelajaran PAI sangat tergantung pada karakteristik materi yang termuat dalam silabus. Ia menyebutkan dua teknik integrasi, yaitu secara langsung dan tidak langsung. ${ }^{39}$

Merujuk pada pendapat Rahman dkk, maka temuan penelitian di kedua situs dapat dijelaskan bahwa integrasi nilai multikultural dengan pendekatan formal-tekstual dilakukan melalui dua teknik, yaitu langsung dan tidak langsung. Pada integrasi langsung, guru mengintegrasikan nilai multikultural dengan materi bercorak multikultural yang relevan dalam silabus seperti: kontrol diri, toleransi, saling menghormati, menolong, persatuan, moderat, Islam rahmatul lil 'alamin dan kebudayaan Islam.

${ }^{39}$ Rahman dkk, Panduan ..., hlm. 120-121. 
Sedangkan pada integrasi tidak langsung, guru mengintegrasikan nilai multikultural melalui materi tentang teologi, ibadah, mu'amalat dengan menarik ajaran moral substantif yang terkandung di dalamnya untuk diteransfer kepada peserta didik dan diaktualkan dalam membangun perdamaian umat beragama di sekolah dan masyarakat Poso.

\section{b. Sosial-Kontekstual}

Berdasarkan temuan penelitian di kedua situs dapat dijelaskan bahwa integrasi nilai multikultural dalam pembelajaran PAI melalui pendekatan sosial-kontekstual dilakukan dengan mengaitkan materi sesuai realitas sosial keragaman peserta didik, warga sekolah yang mayoritas minoritas secara agama, masyarakat Poso yang pernah konflik dan upaya membangun perdamaian umat beragama.

Secara formal, integrasi nilai multikultural dengan pendekatan sosial-kontekstual berhubungan dengan materi tentang pembentukan etika sosial peserta didik terhadap orang atau kelompok lain. Di luar kelas, guru mengintegrasikan nilai multikultural melalui kegiatan keagamaan, kerja sosial dan kemanusiaan lintas budaya dan agama yang mendukung terbangunya perdamaian umat beragama di kedua situs.

Pendekatan sosial-kontekstual yang dominan berlangsung di luar kelas termasuk pada level pendekatan aksi sosial menurut kategori yang kemukakan Banks. ${ }^{40}$ Rahman dkk menyebut lingkup pendekatan aksi sosial secara lebih konkrit, yaitu model integrasi nilai multikultural melalui laboratorium sosial. Pembelajaran PAI tidak hanya berlangsung di kelas, tetapi juga melalui sentra sosial seperti: di masjid, mushalla, unit ekstra kurikuler dan kerja sosial yang menjadi ruang perjumpaan kehidupan peserta didik yang berbeda budaya atau agama. $^{41}$

Proses integrasi nilai multikultural melalui pendekatan sosialkontekstual lebih bersifat praksis daripada teoritis. Peserta didik langsung melaksanakan dialog kehidupan lintas agama berbasis nilai multikultural yang kontekstual dengan realitas keragaman yang ada di sekolah dan kerja-kerja perdamaian yang mereka laksanakan.

Integrasi nilai multikultural melalui pendekatan sosialkontekstual dengan memanfaatkan sentra sosial peserta didik lintas budaya dan agama menarik dikaji dari perspektif teori integrasi sosial Durkheim. Menurutnya, solidaritas sosial dapat melahirkan kesadaran

${ }^{40}$ Banks and Banks, Multicultural ..., hlm. 238.

${ }^{41}$ Rahman dkk, Panduan ..., hlm. 120-121. 
individual dan kolektif dari komunitas berbeda untuk mencapai tujuan bersama. ${ }^{42}$

Merujuk pada pendapat Durkheim, maka kebersamaan peserta didik Islam dan Kristen dalam kerja sosial dan kemanusiaan dilaksanakan berdasarkan solidaritas sosial di antara mereka sehingga melahirkan kesadaran, baik secara individual ataupun kolektif dalam membangun kehidupan yang damai. Perdamaian menjadi misi bersama yang ingin dicapai kedua umat beragama di sekolah dan daerah Poso pasca konflik.

\section{c. Kontributif-Kultural}

Dari temuan penelitan di kedua situs memperlihatkan bahwa integrasi nilai multikultural dalam pembelajaran PAI dengan pendekatan kontributif-kultural dilakukan melalui materi tentang kebudayaan Islam, kultur keagamaan umat Islam dan kearifan lokal masyarakat Poso 'sintuwo maroso' sejalan dengan upaya membangun perdamaian umat beragama di sekolah dan masyarakat Poso.

Kegiatan sosial keagamaan sebagai media mengintegrasikan nilai multikultural secara informal-kontekstual di masing-masing situs tidak sama meraknya. Kondisi ini dipengaruhi oleh posisi umat Islam ketika menjadi kelompok mayoritas atau minoritas di setiap situs. Di SMKN 1 Poso, di mana kehidupan keagamaan sangat diwarnai oleh kultur umat Kristen tentu integrasi nilai multikultural tidak semaksimal seperti di SMAN 3 Poso yang diwarnai oleh umat Islam mayoritas.

Fakta menarik dari pendekatan kontributif-kultural adalah integrasi nilai multikultural dalam pembelajaran PAI melalui aktualisasi kearifan lokal Poso, yaitu 'sintuwo maroso' yang mengajarkan hidup bersama secara damai dalam perbedaan. Kearifan lokal ini sejalan dengan nilai inklusif, toleran dan moderat yang diusung PAI multikultural dalam membangun perdamaian umat beragama di sekolah dan daerah Poso.

Pendekatan integrasi nilai multikultural melalui penerapan kearifan lokal daerah Poso dimaknai sebagai upaya mendialogkan ajaran Islam dengan lokalitas masyarakat di mana Islam dibumikan. Khan menjelaskan bahwa Islam menawarkan visi yang damai di masyarakat yang plural, kapan dan di manapun diaktualkan. Islam

${ }^{42}$ I.B. Wirawan, Teori-teori Sosial dalam Tiga Paradigma: Fakta Sosial, Definis Sosial \& Prilaku Sosial, (Jakarta: Kencana, 2012), hlm. 14. 
menolak sikap hidup yang membedakan satu dengan yang lain karena perbedaan budaya. ${ }^{43}$

Dari pendekatan integrasi materi multikultural yang dikumukakan Banks, pendekatan kontributif-kultural yang menekankan integrasi nilai multikultural melalui topik kebudayaan Islam, kultur keagamaan umat Islam dan kearifan lokal masyarakat Poso termasuk pada pendekatan level kontribusi. Pada level ini, pembelajaran suatu bidang studi dominan mengintegrasikan tematema kebudayaan seperti: pahlawan, tokoh, unsur nasional, kedaerahan dan hari besar keagamaan yang menjadi kultur suatu komunitas. ${ }^{44}$

\section{d. Aditif-Tematik}

Dari temuan penelitan di kedua situs dapat dijelaskan bahwa melalui pendekatan aditif-tematik, guru mengintegrasikan nilai multikultural dalam pembelajaran PAI dengan menambahkan tematema spesifik terkait perdamaian yang meliputi: persaudaraan non muslim, titik temu umat beragama, bahaya radikalisme dan terorisme. Tema perdamaian tersebut diintegrasikan dengan materi bercorak multikultural yang relevan dalam silabus, tidak dibahas secara tersendiri.

Integrasi nilai multikultural dalam pembelajaran PAI melalui tema-tema perdamaian di SMAN 3 Poso lebih menonjol dibandingkan dengan di SMKN 1 Poso. Pada saat pembelajaran di kelas, guru sering menghadirkan peserta didik non muslim, khususnya yang beragama Kristen untuk saling berdialog tentang perbedaan dan persamaan umat beragama. Dengan saling memahami aspek perbedaan yang dimiliki masing-masing umat beragama, maka peserta didik mampu saling menghormati sehingga tidak mudah terjadi konflik bernuansa agama. Demikian pula dengan memahami titik persamaan, mereka dapat bersinergi membangun perdamaian umat beragama di sekolah. Fakta terkait dialog antara peserta didik yang berbeda agama tidak ditemukan pada proses integrasi nilai multikultural dalam pembelajaran PAI di SMKN 1 Poso.

Integrasi nilai multikultural dengan pendekatan aditif-tematik adalah konstektual dengan setting sosial peserta didik yang selalu bersentuhan dengan kehidupan lintas agama dalam membangun perdamaian di sekolah dam masyarakat Poso pasca konflik. Merujuk

43 Maulana Wahiduddin Khan, Islam Anti Kekerasan, Terj. Samson Rahman, (Jakarta: Pustaka Al-Kausar, 2000), hlm. 150-151.

${ }^{44}$ Banks and Banks, Multicultural ..., hlm. 238. 
pada jenis pendekatan yang dikemukakan Banks, maka pendekatan aditif-tematik termasuk pada level aditif yang menekankan hubungan antara komunitas yang berbeda ketika menjadi mayoritas atau minoritas. ${ }^{45}$

Pemilihan tema-tema perdamaian yang kontekstual dengan setting sosial peserta didik di sekolah dan masyarakat pasca konflik dikuatkan oleh pendapat Baidhawy yang mengatakan bahwa materi PAI yang bersifat eksklusif-dogmatis dan cenderung mengabaikan kelompok agama dan budaya minoritas harus dikaji ulang. ${ }^{46}$

Guru di kedua situs, tidak berhenti pada pemilihan tema-tema perdamaian kontekstual, tetapi mengajarkan topik materi yang eksklusif seperti: dogma teologis, makna kafir dan ajaran jihad secara moderat. Dengan cara ini, peserta didik memiliki pemahaman dan sikap beragama yang toleran dalam menyikapi teologi dan ritual ibadah umat agama lain, khususnya peserta didik yang beragama Kristen.

Dari keempat pendekatan integrasi nilai multikultural dalam pembelajaran PAI di atas, peneliti dapat menggambarkan beberapa tahap pengintegrasian yang dilakukan guru di kedua sekolah, yaitu:

1. Memilih dan memberikan penekanan pada nilai multikultural kontekstual yang akan diintegrasikan dengan memperhatikan realitas keragaman peserta didik, setting sosial sekolah, masyarakat Poso yang pernah konflik dan upaya membangun perdamaian.

2. Mengintegrasikan nilai multikultural yang kontekstual terkait upaya membangun perdamaian dengan materi yang relevan atau serumpun di dalam silabus.

3. Pada materi yang tidak bercorak multikultural (teologi, ayat alQur'an dan Hadis, ibadah dan mu'amalat), pengintegrasiaan lima nilai multikultural dilakukan dengan menarik pesan moral subtantif yang penting diaktualkan peserta didik dalam konteks membangun perdamaian umat beragama.

4. Mengintegrasikan nilai multikultural yang kontekstual dalam KD dan IPK hasil belajar dari materi bercorak multikultural secara langsung.

5. Mengintegrasikan nilai multikultural yang kontekstual melalui praktik kearifan lokal masyarakat Poso dalam kegiatan pembelajaran di kelas, ekstra kurikuler, kerja sosial dan kemanusiaan lintas agama di sekolah.

${ }^{45}$ Banks and Banks, Multicultural ..., hlm. 240-241.

${ }^{46}$ Baidhawy, Pendidikan ..., hlm. 112. 
6. Menghubungkan nilai multikultural yang diintegrasikan dengan peristiwa atau realitas kehidupan sosial yang aktual dihadapi peserta didik dalam konteks membangun perdamaian umat beragama di daerah Poso pasca konflik.

\section{Bentuk Integrasi Nilai Multikultural dalam PAI}

Pembahasan bentuk integrasi nilai multikultural dalam pembelajaran PAI di kedua sekolah pasca konflik mengacu pada temuan penelitian lintas situs pada tabel di atas yang diuraikan sebagai berikut:

\section{a. Normatif}

Dari temuan di kedua situs memperlihatkan bahwa integrasi nilai multikultural dalam pembelajaran PAI pada bentuk normatif memiliki muatan dan cakupan yang sama. Pada bentuk normatif ini, integrasi nilai multikultural selalu berkaitan dengan normativitas ajaran Islam, falsafah Pancasila, nilai kebangsaan dan kearifan lokal masyarakat Poso 'sintuwo maroso' sebagai pijakan membangun perdamaian umat beragama dalam konteks kemajemukan warga sekolah, masyarakat dan bangsa Indonesia.

Integrasi nilai multikultural pada bentuk normatif secara formal berlangsung di kelas melalui materi bercorak multikultural atau materi teologi, ibadah dan mua'malat dalam silabus. Sedangkan secara informal berlangsung pada kegiatan keagamaan seperti: kultum, kajian Islam, PHBI, pesantren kilat dan kegiatan sosial keagamaan.

Pendapat Landecker dalam Silis menarik untuk membahas integrasi nilai multikultural dalam bentuk normatif. Ia mengatakan bahwa integrasi normatif dapat membentuk kesepakatan nilai-nilai, norma-norma, cita-cita dan kearifan budaya sebagai solidaritas sosial yang mengikat setiap anggota masyarakat. ${ }^{47}$

Merujuk pada pendapat Landecker di atas, maka temuan penelitian tentang integrasi nilai multikultural pada bentuk normatif di kedua situs selalu berhubungan dengan nilai-nilai agama, falsafah kebangsaan, kearifan budaya dan cita-cita bersama umat Islam dan Kristen dalam membangun perdamaian bersama pasca konflik. Nilai normatif menjadi sistem sosial yang mengatur kedua umat beragama agar tetap berada pada kondisi kehidupan yang harmonis, terhindar dari konflik berlatar perbedaan.

Senada dengan pendapat Landecker, Parekh mengatakan bahwa multikulturalisme bersifat normatif, dimana mengandung falsafah,

${ }^{47}$ David, E. Silis (ed), International Encyclopedia of the Social Science, (New York: The MacMillan Company \& The Free Press, 1986), hlm. 381. 
nilai, prinsip, norma dan pandangan yang dijadikan basis untuk mengelola keragaman kebudayaan yang terdapat pada masyarakat plural. ${ }^{48}$ Menurut Samani dan Hariyanto, dalam praksis pendidikan di Indonesia, integrasi nilai ke dalam pembelajaran pada setiap bidang studi harus bersumber dari ajaran agama, Pancasila, UUD 1945, UU Sisdiknas dan budaya luhur masyarakat Indonesia. ${ }^{49}$ Karena itu, integrasi nilai multikultural dalam pembelajaran PAI pada bentuk normatif berkaitan erat dengan penanaman nilai nasionalisme seperti: falsafah Pancasila, cinta NKRI, menghormati bendera merah putih dan atribut kebangsaan lain.

Jika dilihat dari perspektif teori fakta sosial Durkheim, yaitu: fakta sosial material dan non material. ${ }^{50}$ Maka, integrasi nilai multikultural pada bentuk normatif bersifat non material, sebab mengandung nilai, norma dan kearifan yang berkaitan dengan ajaran Islam, falsafah Pancasila, nilai kebangsaan dan kearifan lokal yang dipedomani guru dan peserta didik membangun perdamaian umat beragama di sekolah dan daerah Poso.

\section{b. Interpersonal}

Berdasarkan temuan penelitian di kedua situs dapat dijelaskan bahwa integrasi nilai multikultural dalam pembelajaran PAI pada bentuk interpersonal dilakukan melalui interaksi peserta didik lintas budaya dan agama terkait upaya membangun perdamaian di sekolah dan masyarakat Poso pasca konflik.

Hubungan interpersonal antara peserta didik muslim yang berbeda secara kultur berlangsung di kelas, islamic center, masjid dan kegiatan sosial keagamaan. Sedangkan hubungan interpersonal dengan peserta didik Kristen dalam konteks membangun perdamaian berlangsung pada kegiatan ekstra kurikuler, kerja sosial dan kemanusiaan.

Integrasi nilai multikultural dalam bentuk hubungan interpersonal oleh Landecker disebut sebagai tipe integrasi komunikatif. Komunitas yang berbeda saling berinteraksi secara

${ }^{48}$ Bikhu Parekh, Rethingking Multicuturalism, Keragaman Budaya dan Teori Konflik, Terj. C.B. Bambang Kukuh Adi, (Yogyakarta: Kanisius, 2008), hlm. 19.

49 Muchlas Samani dan Hariyanto, Pendidikan Karaker: Konsep dan Model, (Cet. V; Bandung: Remaja Rosdakarya, 2016), hlm. 52.

50 George Ritzer, Teori Sosiologi: Dari Sosiologi Klasik sampai Perkembangan Terakhir Posmodern, Terj. Saut Pasaribu dkk, (Yogyakarta: Pustaka Pelajar, 2012), hlm. 131-132. 
sinergis dalam membangun kebersamaan yang sejalan dengan kondisi sosial yang dihadapi suatu masyarakat. ${ }^{51}$

Hubungan interpersonal antara peserta didik muslim yang berbeda secara kultural atau interaksi dengan peserta didik Kristen sejatinya berawal dari pembentukan karakter personal peserta didik. Pada posisi ini, karakter personal peserta didik yang multikulturalreligius dalam interaksi lintas budaya dan agama sangat mendukung terciptanya perdamaian umat beragama di kedua situs.

Dengan demikian, integrasi nilai multikultural seperti: saling memaafkan, kasih sayang, saling menghormati, saling peduli, toleransi, kebersamaan dan sikap damai dalam pembelajaran PAI di kelas atau kegiatan keagamaan bertujuan membentuk karakter personal peserta didik yang multikulturalis-religius sebagai basis menjalin hubungan interpersonal dengan umat agama lain di sekolah dan masyarakat Poso dalam konteks membangun perdamaian.

Dari perspektif teori pembentukan karakter, maka integrasi nilai multikultural pada bentuk interpersonal berawal dari pembentukan karakter personal peserta didik yang toleran dan damai kepada umat agama lain. Dalam konteks ini, Lickona melalui konsep the building characternya mengatakan bahwa pembelajaran di sekolah berperan penting membentuk karakter peserta didik yang meliputi: pengetahuan moral (moral knowing), perasaan moral (moral feeling) dan tindakan moral (moral action). ${ }^{52}$

\section{c. Sosial}

Temuan penelitian tentang integrasi nilai multikultural dalam pembelajaran PAI pada bentuk sosial dilakukan melalui kegiatan sosial keagamaan dan kemanusiaan di sekolah dan masyarakat. Integrasi dalam bentuk sosial merupakan kelanjutan dari integrasi interpersonal. Peserta didik yang memiliki karakter personal yang baik akan mudah menjalani kehidupan sosial lintas budaya dan agama dalam membangun perdamaian di sekolah dan masyarakat Poso pasca konflik.

Dalam pembelajaran di kelas, guru di kedua situs mengintegrasikan nilai multikultural dengan menanamkan nilai, etika sosial dan sekaligus mengintegrasikan peserta didik yang berbeda secara kultural. Sedangkan secara informal, guru memfungsikan kegiatan sosial keagamaan, ekstra kurikuler kerja kemanusiaan untuk

${ }^{51}$ Silis (ed), International ..., hlm. 381.

52 Thomas Lickona, Educating for Character: How Our School Can Teach Respct and Responsibility, (New York: Batam Books, 1991), hlm. 53. 
menyatukan peserta didik Islam dan Kristen dalam membangun perdamaian umat beragama.

Integrasi nilai multikultural dalam bentuk sosial banyak berlangsung secara informal di luar kelas menuntut terjadinya adaptasi berbagai unsur sosial yang ada di sekolah seperti: agama, komunitas dan budaya. Karena itu, integrasi nilai multikultural melalui kegiatan keagamaan dan kerja sosial diselaraskan dengan realitas keragaman warga sekolah dan misi bersama membangun perdamaian. Sanaky mengatakan bahwa integrasi sosial di lembaga pendidikan sebagai proses penyesuaian unsur-unsur yang berbeda agar memiliki keselarasan dalam menjalankan fungsi eduktifnya. ${ }^{53}$

Integrasi nilai multikultural dalam pembelajaran PAI melalui kegiatan sosial ini melibatkan unsur-unsur sosial yang saling terintegrasi oleh Durkheim disebut sebagai fakta-fakta sosial. Ia mengatakan bahwa fakta-fakta sosial tidak dapat direduksi sebagai realitas individu, tetapi harus dilihat sebagai realitas sosial dalam masyarakat yang saling terkait. ${ }^{54}$

Mengacu pada pendapat Durkheim tentang fakta-fakta sosial, maka integrasi nilai multikultural dalam bentuk sosial melalui kegiatan sosial keagamaan dan kemanusiaan lintas agama dalam konteks membangun perdamaian di kedua situs sebagai fakta sosial yang menyatukan umat Islam dan Kristen.

Dalam kehidupan sekolah yang majemuk, integrasi sosial dan budaya sebagai proses membangun kesatuan sosial hanya dapat terwujud jika komunitas berbeda memiliki sikap inklusif. Pada posisi ini, integrasi nilai multikultural dalam pembelajaran PAI pada bentuk sosial ini memiliki relevansi dengan konsep 'ashabiyah Ibn Khaldun yang menekankan agar komunitas yang berbeda saling berintegrasi dalam menguatkan kesatuan masyarakat dan bangsa agar terhindar dari berbagai konflik. ${ }^{55}$

\section{d. Budaya Lokal}

Dari temuan penelitan di kedua situs dapat dijelaskan bahwa integrasi nilai multikultural dalam bentuk budaya lokal dilakukan melalui penerapan kearifan lokal masyarakat Poso, yaitu 'sintuwo maroso' yang mengajarkan hidup bersama secara damai dalam perbedaan. Kearifan lokal 'sintuwo maroso' ini sebagai hidden

53 Hujair AH. Sanaky, Dinamika Pendidikan Islam di Indonesia, (Yogyakarta: Kaukaba, 2016), hlm. 43.

${ }^{54}$ Ritzer, Teori ..., hlm. 132.

${ }^{55}$ Khaldun, Muqaddimah ..., hlm. 371. 
curriculum yang dipedomani seluruh warga sekolah dalam pembelajaran dan kehidupan sosial di sekolah.

Temuan penelitian di masing-masing situs memperlihatkan bahwa integrasi nilai multikultural dalam pembelajaran PAI pada bentuk budaya lokal di SMKN 1 Poso dilakukan melalui dua kearifan, yaitu: 'sintuwo maroso' dan 'padungku'. Sedangkan di SMAN 3 Poso, integrasi nilai multikultural hanya dilakukan melalui kearifan lokal 'sintuwo maroso'.

Perbedaan ini sangat terkait dengan posisi umat Islam sebagai kelompok mayoritas atau minoritas di masing-masing situs. Integrasi nilai multikultural melalui acara budaya 'padungku' di SMKN 1 Poso dimaksudkan untuk membentuk sikap peserta didik yang toleran kepada umat Kristen mayoritas yang merayakannya setiap musim panen sebagai ungkapan syukur kepada Tuhan atas segala karuniaNya.

Dari perspektif tipologi integrasi yang dikemukakan Landecker dalam Silis, maka integrasi nilai multikultural dalam pembelajaran PAI melalui praktik kearifan lokal masyarakat Poso berada pada tipe integrasi budaya dan normatif. ${ }^{56}$ Integrasi antara unsur budaya dan agama yang memiliki keterkaitan nilai secara fungsional, tidak saling bertentangan satu dengan yang lain.

Integrasi nilai multikultural melalui penerapan kearifan budaya lokal dapat dimaknai sebagai upaya umat Islam dan Kristen di kedua situs dalam menyemaikan nilai, norma, simbol dan praktik budaya luhur kepada peserta didik sebagai generasi masa depan bangsa di daerah Poso. Dalam konteks sekolah sebagai agen pelestarian nilai, norma, simbol budaya menarik ditinjau dari pandangan Scupin dan Decorse yang membagi budaya menjadi dua jenis, yaitu budaya material (bangunan, fasilitas, pakaian, simbol) dan budaya immaterial (kayakinan, nilai dan norma). ${ }^{57}$

Secara immateril, integrasi nilai multikultural pada bentuk budaya lokal dilakukan dengan menanamkan falsafah, nilai, etika, norma yang terkait dengan kearifan lokal masyarakat Poso tentang hidup bersama dalam perbedaan secara damai. Sedangkan secara material terlihat pada hari-hari besar keagamaan, peserta didik Islam dan Kristen saling menerima ekspresi simbol dan atribut keagamaan di sekolah secara toleran.

${ }^{56}$ Silis (ed), International ..., hlm. 381.

${ }^{57}$ Raymond Scupin and Christopher R. Decorse, Anthropology: A Global Perspective ${ }^{\text {th }}$ ed, (Boston: Pearson Education, 2016), hlm. 230. 
Keempat bentuk integrasi nilai multikultural dalam pembelajaran PAI di kedua situs di atas menggambarkan serangkaian proses pembentukan karakter beragama peserta didik yang inklusif, toleran dan moderat dalam konteks membangun perdamaian. Pembentukan karakter beragama peserta didik diawali dengan internalisasi nilai-nilai normatif sebagai pijakan melaksanakan hubungan interpersonal lintas agama pada kerja sosial dan kemanusiaan sehingga tercipta budaya damai yang sejalan dengan konteks sekolah dan masyarakat Poso dalam membangun perdamaian pasca konflik.

\section{KESIMPULAN}

Integrasi nilai multikultural dalam pembelajaran PAI sangat penting untuk membangun perdamaian warga sekolah dan masyarakat Poso pasca konflik. Di SMKN 1 Poso, guru mengintegrasikan nilai multikultural yang meliputi: saling memaafkan, kasih sayang, toleransi, kebersamaan dan perdamaian. Sedangkan guru di SMAN 3 Poso mengintegrasikan nilai saling menghormati, kepedulian, toleransi, kebersamaan dan perdamaian. Guru di kedua sekolah menekankan integrasi nilai toleransi, kebersamaan dan perdamaian dalam pembelajaran PAI.

Integrasi nilai multikultural dalam pembelajaran PAI di kedua sekolah pasca konflik memperhatikan konteks keragaman peserta didik, realitas sosial warga sekolah yang mayoritas dan minoritas, masyarakat Poso yang pernah mengalami konflik dan upaya membangun perdamaian.

Integrasi nilai multikultural di kedua sekolah berlangsung secara formal-tekstual di kelas dan informal-konstekstual di lingkungan sekolah atau masyarakat. Integrasi nilai multikultural dilakukan melalui empat pendekatan, yaitu: formal-tekstual, sosial-kontekstual, kontributif-kultural dan aditif-tematik dengan empat bentuk integrasi yang meliputi: normatif, interpersonal, sosial dan budaya lokal.

\section{DAFTAR PUSTAKA}

Azra, Azyumardi. Merawat Kemajemukan, Merawat Indonesia. Yogyakarta: Kanisius, 2007.

Abdullah, M. Amin dalam Kata Pengantar: "Kesadaran Multikultural: Sebuah Gerakan "Interest Minimalization" dalam Meredakan Konflik Sosial” dalam M. Ainul Yaqin, Pendidikan Multikultural: CrossCultural Understanding untuk Demokrasi dan Keadilan. Yogyakarta: Pilar Media, 2005.

Adisusilo, Sutarjo Pembelajaran Nilai Karakter: Konstruktivisme dan VCT Sebagai Inovasi Pendekatan Pembelajaran Afektif. Jakarta: PT. Raja Grafindo Persada, 2012. 
Banks, James A. and Cherry A. McGee Banks, Multicultural Education: Issues and Perspective. Ed.VII, USA: Wiley \& Sons, Inc. 2010.

Baidhawy, Zakiyuddin Pendidikan Agama Berwawasan Multikultural. Jakarta: Erlangga, 2005.

Bogdan, Robert and Sari Knopp Biklen, Qualitative Research for Education; An Introduction to Theory and Methods. London: Allyn and Bacon Inc, 1998.

Hasan, Muhammad Tholhah. Pendidikan Multikultural sebagai Opsi Penanggulangan Radikalisme. Malang: Universitas Islam Malang, 2016.

Jamaludin, Adon Nasrullah. Agama \& Konflik Sosial: Studi Kerukunan Umat Beragama, Radikalisme, dan Konflik AntarUmat Beragama. Bandung: Pustaka Setia, 2015.

Kamus Besar Bahasa Indonesia Online, https://www.kbbi.my.id/kata/integrasi. Diakses, tanggal 15 November 2019. https://kbbi.web.id/nilai.html. Diakses, tanggal 25 November 2019.

Kementerian Pendidikan dan Kebudayaan, Silabus Mata Pelajaran Pendidikan Agama Islam dan Budi Pekerti SMA/MA/SMK/MAK, Edisi Revisi, (Jakarta: Kementerian Pendidikan dan Kebudayaan, 2016.

Khaldun, Ibnu. Muqaddimah Ibn Khaldun, Terj. Ahmadie Thoha. Jakarta: Pustaka Firdaus, 2000.

Khan, Maulana Wahiduddin. Islam Anti Kekerasan, Terj. Samson Rahman. Jakarta: Pustaka Al-Kausar, 2000.

Lickona, Thomas. Educating for Character: How Our School Can Teach Respct and Responsibility. New York: Batam Books, 1991.

M.D, Mahfud. Demokrasi dan Konstitusi di Indoenesia. Yogyakarta, Liberty, 1993.

Mitchell, Bruce M. and Robert E. Salsbury, Encyclopedia of Multicultural Education. London: Greenwood Press, 1999.

Milles, Matthew B., Michael Huberman and Johnny Saldana, Qualitative Data Analysis: A Methods Saourcebook. Ed. III; USA: SAGE Publication.Inc, 2014.

Parekh, Bikhu. Rethingking Multicuturalism, Keragaman Budaya dan Teori Konflik, Terj. C.B. Bambang Kukuh Adi. Yogyakarta: Kanisius, 2008.

Race, Ricard. Multiculturalism and Education: Comtemporary Issues in Education Studies. Great Britain, Continuum, 2011.

Rahman, H. Abd. dkk, Panduan Integrasi Nilai Multikultural dalam Pendidikan Agama Islam pada SMA dan SMK. Jakarta: PT. Kirana Cakra Buana, 2011. 
Ritzer, George. Teori Sosiologi: Dari Sosiologi Klasik sampai Perkembangan Terakhir Posmodern, Terj. Saut Pasaribu dkk. Yogyakarta: Pustaka Pelajar, 2012.

Silis, David, E. (ed), International Encyclopedia of the Social Science. New York: The MacMillan Company \& The Free Press, 1986.

Samani, Muchlas dan Hariyanto, Pendidikan Karaker: Konsep dan Model, (Cet. V; Bandung: Remaja Rosdakarya, 2016.

Sanaky, Hujair AH. Dinamika Pendidikan Islam di Indonesia. Yogyakarta: Kaukaba, 2016.

Scupin, Raymond and Christopher R. Decorse, Anthropology: A Global Perspective $8^{\text {th }}$ ed. Boston: Pearson Education, 2016.

Wirawan, I.B. Teori-teori Sosial dalam Tiga Paradigma: Fakta Sosial, Definis Sosial \& Prilaku Sosial. Jakarta: Kencana, 2012. 